\title{
The Great Risk Shift? \\ Income Volatility in an International Perspective
}

\author{
Claudia M. BuCH
}

CESIFO WORKING PAPER NO. 2465

CATEGORY 4: LABOUR MARKETS

NOVEMBER 2008

\footnotetext{
An electronic version of the paper may be downloaded

- from the SSRN website:

www.SSRN.com

- from the RePEc website:

- from the CESifo website:

www.RePEc.org

www.CESifo-group.org/wp
} 


\title{
The Great Risk Shift? Income Volatility in an International Perspective
}

\begin{abstract}
Weakening bargaining power of unions and the increasing integration of the world economy may affect the volatility of capital and labor incomes. This paper documents and explains changes in income volatility. Using a theoretical framework which builds distribution risk into a real business cycle model, hypotheses on the determinants of the relative volatility of capital and labor are derived. The model is tested using industry-level data. The data cover 11 industrialized countries, 22 manufacturing and services industries, and a maximum of 35 years. The paper has four main findings. First, the unconditional volatility of labor and capital incomes has declined, reflecting the decline in macroeconomic volatility. Second, the idiosyncratic component of income volatility has hardly changed over time. Third, crosssectional heterogeneity in the evolution of relative income volatilities is substantial. If anything, the labor incomes of high- and low-skilled workers have become more volatile in relative terms. Fourth, income volatility is related to variables measuring the bargaining power of workers. Trade openness has no significant impact.
\end{abstract}

JEL Code: E32, E25.

Keywords: income volatility, distribution risk, real business cycles.

\author{
Claudia M. Buch \\ University of Tübingen \\ Department of Economics \\ Mohlstrasse 36 \\ 72074 Tübingen \\ Germany \\ claudia.buch@uni-tuebingen.de
}

November 2008

This paper has been written during visits of the CES Institute in Munich (Germany) and the National Bureau of Economic Research (NBER) in Cambridge, MA. The hospitality of these institutions as well as financial support from the Thyssen Foundation are gratefully acknowledged. I would like to thank participants of a seminar at the University of Groningen, in particular Marcel Timmer, Robert Inklaar, and Michael Kötter, as well as Bernhard Boockmann, Jörg Breitung, Jörg Döpke, and Bernd Fitzenberger for most helpful discussions and comments. Benjamin Guin and Daniela Harsch have provided highly efficient research assistance. All errors and inconsistencies are solely in my responsibility. 


\section{Motivation}

Changes in labor market institutions and the increasing integration of the world economy may affect the volatility of capital and labor incomes, both in absolute and in relative terms. For the United States, it has been argued that households bear greater risks than they used to because of a shift in risk from the corporate to the private sector (Hacker 2006). Empirical studies find mixed evidence on the link between globalization and risk. Scheve and Slaughter (2004) report survey evidence which links perceived economic insecurity to the globalization process. A recent OECD study does not find a link between job market instability and globalization though (OECD 2007).

One measure of changing risk patterns are changes in income volatility. Yet, while there is a large empirical literature on volatility at the aggregate, industry-, or firm-level, little is known about changes in the relative volatility of capital and labor incomes. At the aggregate level, there has been a Great Moderation in aggregate output volatility (Blanchard and Simon 2001, Stock and Watson 2002), but literature on the evolution of firm-level volatility has remained inconclusive (Davis and Kahn 2007). Household-level studies on income volatility based on US data show an increase in the volatility of earnings (Comin et al. 2006, Shin and Solon 2008) and consumption (Gorbachova 2007). Others argue that an increase in income volatility has not been a universal phenomenon (Jensen and Shore 2008). Earlier research has also used cross-country data on consumption volatility (Kose et al. 2007) or industry-level data on output volatility (Di Givanni and Levchenko 2008, Braun and Larrain 2005). None of these papers studies changes in the volatility of labor income across countries or industries, in particular in relation to the volatility of capital income.

This paper studies changes in the volatility of labor and capital incomes. For this purpose, industry-level data for 11 industrialized countries, 22 manufacturing and services industries, and a maximum time period of 35 years (1970-2004) are used. The paper addresses the following three questions. First, what have been the trends in the absolute volatility of labor and capital income across industrialized countries? Second, has the volatility of labor income relative to that of capital income changed? Third, what are the determinants of income volatility? 
The empirical analysis is motivated by a real business cycle model with distributional risk (Danthine, Donaldson, and Siconolfi 2008). ${ }^{1}$ The model features two types of agents workers who do not hold financial assets and shareholders who own the capital stock of the economy. Hence, financial market participation is limited. The income of workers is insured against idiosyncratic shocks via an implicit insurance contract. The terms of this contract are related to social factors, political preferences, and the degree of competition on global markets. The distribution of incomes is subject to stochastic shocks, which interact with standard productivity shocks. Distributive shocks have an impact on the level of incomes as well as on the volatility of incomes. ${ }^{2}$ The implications of the model are brought to the data by testing the impact of industry-specific volatility, political preferences, and trade openness on the volatility of labor and capital incomes. ${ }^{3}$

The model's assumption that financial market participation is limited is supported by empirical studies. Mankiw and Zeldes (1990) find that a substantial fraction of US households does not participate in the stock market. And despite the increase in the width and depth of financial markets since the early 1990s, households' financial assets remain highly concentrated within a relative small share of the population. (See Lusardi and Mitchell (2007) for the US or DIW (2007) for Germany.) Hence, many households must resort to partial insurance mechanisms to smooth consumption fluctuations outside credit markets (Blundell et al. 2008), including within-firm insurance mechanisms of the type studied in Danthine et al. (2008).

In line with most of the literature in the field, volatility is measured as the standard deviation of the idiosyncratic component of income growth in an industry. The idiosyncratic or conditional component of income growth is extracted using the multifactor residual model by Pesaran (2006). This model accounts for observed and unobserved common factors affecting incomes, and the response to these factors is allowed to be heterogeneous across industries.

\footnotetext{
1 The focus of their paper is on an explanation for the equity risk premium.

2 Bottazzi et al. (1996) show that redistributive shocks such as shifts in the bargaining power of workers affect the correlations between capital and labor income as well. In contrast, the focus in this paper is on the volatility of income.

3 A related branch of the labor market literature analyzes the correlation between labor income and profits at the firm-level. (See, e.g., Nickell and Wadhwani (1990) for the UK or Gürtzgen (2005) for Germany.)
} 
This paper has five parts. In Part Two, I describe the database and provide key descriptive statistics for income volatility. In Part Three, hypotheses on the determinants of income volatility are derived from a theoretical model by Danthine et al. (2008). In Part Four, the determinants of absolute and relative volatilities of capital and labor income are analyzed. Part Five concludes. Results highlight the importance of distinguishing between idiosyncratic and macroeconomic factors contributing to industry-level volatility. Unconditional volatility of labor and capital incomes has shown a similar downward trend as aggregate GDP - there has been a Great Moderation of incomes. Once macroeconomic factors are accounted for, time trends are less distinct. If anything, the relative volatility of the income of low-skilled workers has increased. Regression results show that a higher bargaining power of labor lowers the volatility of labor income. Trade openness has no significant impact.

\section{Descriptive Statistics}

While it is often presumed that labor income volatility has increased, little cross-country evidence on income volatility exists. Most studies focus on the volatility of output at the industry-level ${ }^{4}$ or use household-level data for selected countries such as the US. ${ }^{5}$ Before turning to possible explanations for changes in income volatility, stylized facts on the evolution of the volatility in labor and capital incomes across countries, industries, and time are thus be presented. This section starts with a description of the database and the method used to compute volatilities. Note that the focus of this section is mostly descriptive. Explanations for volatility patterns will be given below (Sections 3 and 4).

\subsection{Industry-level Data}

This paper uses industry-level data from the EUKLEMS database, which provides detailed growth accounting information for Europe, Japan, and the United States. ${ }^{6}$ The data cover the period 1970-2005, and they include primary, secondary, and tertiary industries. One advantage of these data is that they give consistent measures of the compensation of capital,

$4 \quad$ See, e.g., Di Giovanni and Levchenko (2008) or Braun and Larrain (2005).

5 See, e.g., Shin and Solon (2008), Davis and Kahn (2007), Jensen and Shore (2008), or Comin et al. (2006).

6 See Timmer et al. (2007) for a more detailed description of the data and of methodological issues. DewBecker and Gordon (2007) use these data to study the link between employment growth and productivity. 
the compensation of labor, and on productivity. Labor compensation is also split into the compensation of high-skilled, medium-skilled, and low-skilled workers. As workers at different skill-levels are likely to differ in their access to capital markets and their ability to insure risks, this information is particular valuable for the purpose of this paper.

Restricting the analysis to those countries which provide a breakdown of labor compensation by skill level gives a dataset for 22 industries and 11 countries. Details on the data are given in the appendix; Table 1 provides summary statistics. Because information on incomes by skill level are available only starting in the 1980s for some countries, two panel datasets are created:

o Panel 1 is “short and wide”. It contains 11 countries (Austria, Denmark, Spain, Finland, France, Germany, Italy, Japan, Netherlands, UK, USA), 22 sectors, and 21 years (1982-2002). The total cross-section dimension is $N=241$.

o Panel 2 is "long and narrow”. It contains four countries (Germany, Italy, UK, USA) $(N=87)$. It runs from 1970 to $2004(T=35)$.

The focus is on income volatility. From a welfare perspective, a more relevant measure of volatility or risk facing private households might be the volatility of consumption. This paper does not use consumption data for two reasons. First, reliable information on the consumption of workers by industry and across different countries is, to the best of my knowledge, not available. Moreover, I am interested in a comparison of the volatility of capital and labor incomes, and the industry-level statistics used here provide consistent measures of these types of incomes. Second, volatility of incomes can be considered a proxy for the volatility of consumption, in particular for rule-of-thumb consumers who do not have access to credit markets to smoothen consumption over time.

\subsection{Measuring Conditional and Unconditional Volatility}

In Section 3 below, I will present a theoretical model explaining how implicit contracts insure workers against idiosyncratic volatility. To bring the implications of this model to the data, the idiosyncratic component of income volatility needs to be distinguished from the macroeconomic component. This idiosyncratic volatility will be labeled conditional volatility whereas the unconditional volatility additionally captures macroeconomic factors.

The measure of conditional volatility used here is the residual of a regression of log income growth on macroeconomic factors. Not all of these macroeconomic factors are readily observable. Instead, some unobserved factors may hit all sectors and countries alike. To 
distinguish observed and unobserved macroeconomic factors, the multifactor residual model by Pesaran (2006) is used. The logic of this model is as follows. Suppose that income growth is given by:

$$
\hat{y}_{i t}=\alpha_{i}^{\prime} d_{t}+\beta_{i}^{\prime} x_{i t}+\varepsilon_{i t}
$$

where $i=1,2, \ldots, N$ is the number of cross sections (industry-country pairs) and $t=1,2, \ldots, T$ is the number of years. Equation (1) states that income growth depends on a $k \times 1$ vector of observable macroeconomic factors $\left(d_{t}\right)$ and a vector of observed regressors $\left(x_{i t}\right)$. The errors are assumed to have a multifactor structure:

$$
\varepsilon_{i t}=\gamma_{i}^{\prime} f_{t}+u_{i t}
$$

where $f_{t}$ is an $m \times 1$ vector of unobserved macroeconomic factors, and $u_{i t}$ are the individualspecific (idiosyncratic) errors which are assumed to be distributed independently of $d_{t}$ and $x_{i t}$. The unobserved factors can be correlated with $d_{t}$ and $x_{i t}$, hence the individual-specific regressors are modeled according to:

$$
x_{i t}=A_{i}^{\prime} d_{t}+\Gamma_{i}^{\prime} f_{t}+v_{i t}
$$

where $A_{i}$ and $\Gamma_{i}$ are factor loading matrices, and $v_{i t}$ are components of $x_{i t}$ which are independent of the macroeconomic factors.

In most applications, the interest is in the slope coefficient $\beta_{i}$ in equation (1). Instead, the main interest in this paper is the idiosyncratic term $u_{i t}$, which gives the idiosyncratic component of income growth which is uncorrelated to observed and unobserved macroeconomic factors. The key challenge is to isolate developments at the industry-level from aggregate developments while taking into account that some of the macroeconomic factors are unobserved. To isolate factors which affect all industries and countries $\left(d_{t}, f_{t}\right)$ from country-industry-specific variables $\left(x_{i t}\right)$, income growth is thus regressed on observed and unobserved macroeconomic factors. These regressions are run separately for each of the cross-sections, and the residuals from these regressions are retained.

This multifactor residual model is applied to the "long and narrow" panel, including four observed macroeconomic factors $\left(d_{t}\right)$ (growth in GDP per capita, inflation, energy prices, and trade openness). Following Pesaran (2006), the unobserved macroeconomic factors $\left(f_{t}\right)$ can be proxied through the sample means of country-industry-specific variables. This paper 
uses output growth, mean TFP growth, and the mean change in relative prices across industries. The dependent variable is the log growth rate of labor or capital income, respectively.

Since the multifactor residual model requires sufficiently long time series, the methodology described above cannot be applied to the "short and wide" panel. For this panel, the idiosyncratic component of income growth is obtained by running a pooled regression of log income growth on a full set of country-year, industry-year, and country-industry fixed effects. The purpose of these regressions is to demean income growth rates and to purge then from macroeconomic developments affecting all sectors and countries alike. These regressions are run for each of the skill groups separately, thus accounting for skill-specific trends in wages (see Katz 1994).

With a measure of idiosyncratic income growth at hand, rolling average standard deviations of growth rates over a five year window are computed:

$$
\sigma\left(\hat{u}_{i t}\right)=\frac{1}{4} \sqrt{\sum_{k=1}^{5}\left(\hat{u}_{i, t+k}-\overline{\hat{u}}_{i}\right)^{2}}
$$

where $\hat{u}_{i t}$ is the idiosyncratic component of income growth obtained as the residual of the

regressions described above, and $\overline{\hat{u}}_{i}$ is the corresponding mean. Equation (4) is applied to the volatility of incomes at different skill levels and to capital income.

\subsection{Income Volatility}

Graph 1 plots income volatility, distinguishing the "wide and short” Panel 1 (Graphs 1a-1d) from the "long and narrow” Panel 2 (Graphs 1e-1g). ${ }^{7}$ For each of these panels, the volatility of labor incomes (Graphs 1a and 1e), of capital income (Graphs 1b and 1f), and the relative volatility of labor incomes as the ratio between these two (Graph 1c and 1g) are plotted. Graph 1d additionally shows trends in the shares of capital and labor in total income. Overall, the median labor share across industries and countries has fluctuated between 0.71 and 0.75 in the 20 years under study for Panel 1. Breaking up labor income shows an increase in the 
compensation going to high- and medium-skilled workers and a decline in the share going to low-skilled workers. ${ }^{8}$

In Graphs 1a and 1b, the absolute volatilities of conditional and unconditional labor and capital incomes are plotted. The unconditional volatility is represented by the dashed lines. There has been a negative time trend, which has partly reversed in recent years. In this sense, there has been a Great Moderation not only with regard to output volatility but also in the volatility of labor and capital incomes. While exhibiting similar trends, the volatility of capital income has been about twice as high as the volatility of labor incomes.

At the aggregate level, the causes for the Great Moderation in terms of output volatility are subject to a lively debate. The jury is still out on the question whether "Good Policy", in particular a more stabilizing monetary policy, or "Good Luck”, i.e. the absence of major shocks, is the main cause of the Great Moderation. (See Benati and Surico (2008) or Giannone et al. (2007) for recent contributions to this debate.) This paper does not take a stance in this debate. Instead, it uses macroeconomic factors to compute idiosyncratic volatilities which capture both sets of explanations.

After accounting for macroeconomic factors, time trends of the idiosyncratic component of volatility, given by the solid lines, look different. Not only has the conditional volatility of labor income been only about one third to one half of the unconditional volatility, it has also shown no marked trend over time. ${ }^{9}$ As a consequence, the gap between the unconditional and the conditional volatility of labor income has narrowed. The relative importance of idiosyncratic volatility, in other words, has increased. By and large, the time series properties of volatilities computed for the "long and narrow" Panel 2 (Graphs 1e and 1f), which are based on the multifactor residual model described above, confirm these findings.

The similar time patterns of volatilities for capital and labor income might indicate that relative volatilities have not changed much. Graphs $1 \mathrm{c}$ and $1 \mathrm{~g}$ show that this is not generally the case. Looking at Panel 1 first, the unconditional relative volatility of labor income (Graph 1c) has shown a weak downward trend, which has reversed in recent years. The relative idiosyncratic volatility has been much lower throughout, and it has declined for total

\footnotetext{
8 Behind these numbers are, of course, changes in the total amount of hours worked and in wages per hour.

$9 \quad$ This is consistent with earlier findings in Gottschalk and Moffit (1994) who report no significant trend in their conditional measure of income volatility at the sector level.
} 
employment, medium- and high-skilled employment. For low-skilled employment, in contrast, it has increased. Relative idiosyncratic volatility has, in addition, been consistently below relative total volatility. This is consistent with the hypothesis that capital owners have a greater exposure to idiosyncratic risk than workers.

Evidence for the longer Panel 2 and using the Pesaran-methodology described above (Graph 1g), confirm the major findings for Panel 1. Similar time trends for income volatility at the household level have been reported by Gottschalk and Moffit (1994).

Prima facie, these changes in relative volatility over time could be taken as evidence that risksharing mechanisms within sectors have changed. Table 2 provides more formal tests of changes in absolute and relative volatilities over time, distinguishing between countries and industries. The year 1990 is chosen as a breakpoint. Using the year 1985 instead, which is typically considered the start of the Great Moderation period, for the "long and narrow" panel gives similar qualitative results. Table 2 gives the difference in volatilities moving from the first to the second period, i.e. a positive sign indicates that volatility has fallen, and a negative sign indicates that volatility has increased. The table also reports results of one-sided $t$-tests for the significance of differences in the means.

Table 2 shows that the changes in median volatility reported in Graph 1 hide a substantial degree of heterogeneity in volatility patterns. Considering the distinction between industries first (Table 2a), there is a relative consistent pattern of a decline in absolute labor income volatility, which is driven by medium-skilled employment. For relative volatilities as well as for the volatility of high-skilled labor compensation and capital compensation, patterns are more heterogeneous. There is no clear dividing line between manufacturing and services industries in terms of changes in volatilities over time.

As regards the distinction between workers at different skill levels, the picture for total and medium-skilled employment is mixed. In some sectors, relative volatilities have increased. In others, volatilities have decreased. For low-skilled workers, in contrast, there has been an increase in relative volatilities. In 11 out of 20 industries, volatilities of low-skilled labor income have increased significantly. Relative volatilities of high-skilled labor income have increased as well, but these increases are significant in only four industries. Breaking down the data by country (Table 2b) gives a similar tendency of an increase in relative volatilities of high- and low-skilled workers' incomes.

By and large, the results using Panel 1 and Panel 2 are similar in terms of the time trends in the data. Since Panel 1 provides richer cross-section dynamics than Panel 2, the main 
regressions results that follow in Part 4 will be based on Panel 1, the "short and narrow" panel.

\section{Relative Income Volatility and Distribution Risk: A Theoretical Illustration}

One finding of the previous section is that, overall, the volatility of labor and capital incomes has fallen. At the same time, the relative volatility of labor income has increased in some countries and industries, particularly for low-skilled workers. A standard neoclassical model with competitive labor markets and a Cobb-Douglas technology would have difficulties explaining these patterns in the data. In such a model, factors shares would be constant, and labor and capital income would fluctuate proportionally with the volatility of output or TFP. This section summarizes the implications of a real business cycle (RBC) model by Danthine et al. (2008) which helps explaining the stylized facts in the data. The main departure from standard RBC models are the assumptions of a redistributive shock and of limited asset market participation. Via an implicit insurance contract, workers are insured against idiosyncratic shocks, and labor income varies less than proportionally with output. Workers pay for this insurance contract by accepting lower incomes. Shareholders, in contrast, have a more volatile income and are compensated by a higher equity premium.

The model assumes two types of agents, shareholders $(S)$ with a utility function $u\left(C_{i}^{S}, C_{i}^{S^{*}}\right)$ and workers $(W): u\left(C_{i}^{W}, C_{i}^{W^{*}}\right)$. Labor input is normalized to one: $L=1$. Here, $\left(C_{i}^{S}, C_{i}^{W}\right)$ denotes the consumption of domestic (i) workers and of shareholders of the home firm, and $\left(C_{i}^{s^{*}}, C_{i}^{\mathrm{W}^{*}}\right)$ denotes the corresponding consumption of the foreign good. Foreign variables are denoted by an asterix. The model presented here departs from the closed-economy model in Danthine et al. (2008) by assuming that households consume domestic and foreign goods. Changes in relative prices for these goods thus add a potential insurance mechanism. The aggregate constraints in this economy are given by

$$
\begin{aligned}
& C_{i, t}^{S}+C_{i, t}^{W}+C_{j, t}^{S}+C_{j, t}^{W}+I_{t} \leq f\left(K_{t}, L_{t}\right) \lambda_{t} \\
& K_{t+1}=(1-\delta) K_{t}+I_{t} \\
& C_{i}^{S^{*}}+C_{i}^{W^{*}}=-\left(C_{j}^{S}+C_{j}^{W}\right)
\end{aligned}
$$


where $f\left(K_{t}, L_{t}\right)$ describes the production technology, $\lambda_{t}=$ technology shock, $\delta=$ rate of depreciation, $C_{j}^{S}, C_{j}^{W}=$ consumption of foreign $(j)$ workers and shareholders of the home good, and $C_{j}^{S^{*}}, C_{j}^{W^{*}}=$ consumption of the foreign good. Investment and holdings of the capital stock are purely domestic, i.e. there is trade in goods only. Equation (5) gives the resource constraint, equation (6) describes the process of capital accumulation, and equation (7) is the balance of payments constraint.

Since workers do not participate in financial markets, they optimally choose the level of consumption of domestic and foreign goods as well as their optimal labor input:

$$
\max _{c_{i, t}^{W}, c_{i, t}^{W *}, L_{t}^{W}} E_{o} \sum_{t=0}^{\infty} \beta^{t} u\left(c_{i, t}^{W}, c_{i, t}^{W^{*}}\right) \text { s.t. } c_{i, t}^{W}+p_{t} c_{i, t}^{W^{*}} \leq w_{t} l_{t}^{W}, l_{t} \leq 1
$$

where $\beta=$ discount factor, $c_{t}^{W}=$ period consumption, and $p_{t}=$ relative price of foreign goods (in units of the domestic goods). Optimizing (8) gives three first order conditions. According to the first, workers always consume their full income: $c_{i, t}^{L}+c_{i, t}^{L^{*}}=w_{t}$. Workers thus behave as "rule-of-thumb” consumers. According to the second condition, workers work their full-time endowment: $l_{t}=1$. Finally, they choose their consumption of domestic and foreign goods such that the marginal rate of substitution equals the relative price of the two goods: $p_{t} \frac{\partial u(\cdot)}{\partial c_{i, t}^{W^{*}}}=\frac{\partial u(\cdot)}{\partial c_{i, t}^{W}}$. By adjusting the relative consumption of home and foreign goods, households can partly insure their consumption against fluctuations in income.

The optimization problem of shareholders is more complex since they not only choose the optimal level of consumption but also the optimal holdings of stocks and bonds:

$$
\max _{c_{i, t}^{S}, c_{i, t}^{S^{*}, z_{t}, b_{t}}} E_{o} \sum_{t=0}^{\infty} \beta^{t} u\left(c_{i, t}^{S}, c_{i, t}^{S^{*}}\right) \text { s.t. } c_{t}^{S}+p_{t} c_{t}^{S^{*}}+q_{t}^{e} z_{t+1}+q_{t}^{b} b_{t+1} \leq\left(q_{t}^{e}+d_{t}\right) z_{t}+b_{t}
$$

where $q_{t}^{e}=$ stock price, $q_{t}^{b}=$ bond price, $z_{t}=$ stock holdings, $b_{t}=$ holdings of one-period discount bonds, and $d_{t}=$ dividend. The corresponding first order conditions for stocks, bonds, and relative consumption are given by:

$$
\begin{aligned}
& u_{1}\left(c_{t}^{s}\right) q_{t}^{e}=\beta E_{t}\left\{u_{1}\left(c_{t+1}^{s}\right)\left[q_{t+1}^{e}+d_{t+1}\right]\right\} \\
& u_{1}\left(c_{t}^{s}\right) q_{t}^{b}=\beta E_{t}\left\{u_{1}\left(c_{t+1}^{s}\right)\right\}
\end{aligned}
$$




$$
p_{t} \frac{\partial u(\cdot)}{\partial c_{i, t}^{S *}}=\frac{\partial u(\cdot)}{\partial c_{i, t}^{S}}
$$

Equations (10a) and (10b) show how shareholders allocate their consumption optimally over time, equation (10c) gives the intra-temporal optimization condition. Only the latter insurance mechanism is also available to workers.

Finally, there is a representative firm which maximizes its pre-dividend stock market value $\left(d_{t}+q_{t}^{e}\right)$ period-by-period choosing the optimal level of investment $\left(i_{t}\right)$, and taking the optimization of shareholders into account:

$$
\max _{i_{t}, l_{t}} d_{t}+q_{t}^{e} \equiv d_{t}+E_{t}\left\{\beta \frac{u_{1}\left(c_{t+1}^{s}\right)}{u_{1}\left(c_{t}^{S}\right)}\left(q_{t+1}^{e}+d_{t+1}\right)\right\}
$$

under the following constraints:

$$
\begin{aligned}
& d_{t}=f\left(k_{t}, l_{t}\right) \tilde{\lambda}_{t}-l_{t} w_{t}-i_{t}-b_{t}+b_{t} q_{t}^{b} \\
& k_{t+1}=(1-\delta) k_{t}+i_{t}, l_{t}=1 \\
& \tilde{\mu}_{t} u_{1}\left(c_{t}^{W}\right)=u_{1}\left(c_{t}^{s}\right)
\end{aligned}
$$

The only non-standard element in this model is the risk-sharing contract given by (12c). It states that optimal risk sharing between owners and workers takes place on a period-by-period basis after $\mu_{t}$ has been determined. ${ }^{10}$ If $\mu_{t}=1$, the marginal utilities of high- and low-skilled workers would be identical. In the more general case $\left(\mu_{t} \neq 1\right)$, marginal utilities are proportional to each other. Shareholders equalize their marginal utilities across time and states of nature by participating in financial markets. ${ }^{11}$ By assumption, workers do not participate in financial markets, but the risk-sharing contract indirectly allows them to smooth consumption across states of nature as well. In this sense, labor markets are assuming a risk-sharing function (Danthine and Donaldson 1989). The steady-state value of $\mu_{t}$ is determined by a bargaining process which is outside the scope of this model. It is subject to stochastic fluctuations. By incorporating such a mechanism into an otherwise standard RBC model,

\footnotetext{
10

An alternative modeling strategy would be to assume the presence of a central planner who allocates consumption based on a social welfare function with $\mu_{t}$ being the weight of workers.

11 Risk diversification in this model takes place with regard to different states of nature. Similar implications would hold in a multi-industry model in which risks can be diversified across industries.
} 
implications of $\mu_{t}$ not only for relative consumption shares but also for the relative volatility of labor and capital income can be derived.

The firm's first order conditions are given by:

$$
\begin{aligned}
& u_{1}\left(c_{t}^{s}\right)=\beta E_{t}\left\{u_{1}\left(c_{t+1}^{s}\right)\left[f_{1}\left(k_{t+1}, n_{t+1}\right) \lambda_{t+1}+(1-\delta)\right]\right\} \\
& \mu_{t} u_{1}\left(c_{t}^{W}\right)=u_{1}\left(c_{t}^{s}\right) \\
& l_{t}=1
\end{aligned}
$$

Imposing equilibrium conditions and resource constraints, the first order conditions for workers, shareholders, and for the firm define the equilibrium of the economy.

The model has the following implications for the volatility of absolute and relative incomes. First, implicit contracts insure workers against fluctuations of income due to technology shocks. The income of workers should thus not fluctuate with idiosyncratic, industry-specific changes in TFP if implicit contracts provide full insurance. Also, the income of workers should be smooth relative to the income of shareholders. This result is in line with the empirical evidence presented in Graph 1, which consistently shows a lower volatility of labor incomes than of capital income. Note that this does not imply that the consumption of shareholders is more volatile. Instead, shareholders smooth their consumption by diversifying their income via financial markets and across different industries. This is not reflected in their income earned in a specific industry.

Second, labor market arrangements that affect the implicit contract between workers and shareholders have an impact on the volatility of relative incomes. The lower the bargaining power of workers, the higher is the relative volatility of their incomes. These labor market arrangements can be defined in a narrow sense as reflecting union density, but they can also reflect societal and political preferences concerning income volatility.

Third, the impact of increased trade on the volatility of consumption is ambiguous. On the one hand, increased competitive pressure from abroad and the "threat of offshoring” might weaken the bargaining power of workers. Hence, the volatility of their incomes could increase. Note that, in the above model, the bargaining power of workers is not modeled explicitly. Harrison (2002) has a model in which the bargaining strength of workers depends on global market conditions. She argues that the labor share will fall when it becomes less costly to relocate capital, when it becomes more costly to relocate labor, or when the foreign wage premium falls. On the other hand, workers can use adjustments in the composition of 
their consumption basket to smooth shocks. This possibility of consumption smoothing would not be reflected in their labor incomes.

Fourth, the focus of the theoretical model is on the insurance of workers against idiosyncratic and thus industry-specific shocks. At least in a domestic context, macroeconomic shocks are not insurable and should affect workers and shareholders alike. Hence, the focus of the empirical analysis will be on assessing the importance of risk-sharing mechanisms for workers' relative idiosyncratic income risk. The analysis will be based on the conditional volatility measures described above.

Fifth, Danthine and Donaldson (1989) use an overlapping generation's model and distinguish between old (high-skilled) workers, young (low-skilled) workers, and the owners of the capital stock. Old workers and capital owners enter into a risk-sharing contract similar to the one described above. For young workers, such contracts are not available. These workers receive consumption insurance via unemployment insurance which is paid by taxing the firms. The implication is that incomes of young, low-skilled workers should be more volatile than incomes of high-skilled workers. Following this logic, more generous unemployment insurance as an alternative insurance mechanism should increase the volatility of labor incomes.

\section{Determinants of Income Volatility}

The theoretical model presented above suggests a number of variables which affect the relative volatility of labor and capital income such as the bargaining power of workers, trade integration, or political preferences. This section starts by presenting measures for these variables, which are then used to explain the absolute and relative volatilities of capital and labor.

\subsection{Explanatory Variables}

Bargaining power: The bargaining power of workers is measured in four ways. First, from Bassanini and Duval (2006), country-level information on union density is obtained. Higher union density should be associated with a higher bargaining power of workers and a lower volatility of labor incomes. Second, the share of high-, medium-, and low-skilled workers in total employment in each industry as provided in EUKLEMS is included. This variable also picks up shifts in the relative demand for labor in each skill group over time. Third, the labor 
share in each industry is added as a regressor. ${ }^{12}$ In a Cobb-Douglas-world, this variable should not change much over time, and it should have no impact on the volatility of labor income. Yet, as Graph 1d shows, labor shares have changed over time. It will be tested whether this has had an impact on income volatility. Fourth, for the US, time-varying information on union membership by industry is used.

International openness: The degree of international openness of a sector could affect the bargaining between workers and owners through a "threat of offshoring". The result could be an increase in the income volatility of workers. ${ }^{13}$ This threat could be measured through the degree of offshorability of tasks that are performed in a given industry. Yet, including an offshoring measure directly has not been feasible as, to the best of my knowledge, proxies for services offshoring for a large set of countries, sectors, and years, are not available. (See Jensen and Kletzer (2007) for a recent survey.) Openness is therefore measured through the export share in production and the import penetration ratio taken from the OECD's STAN database. This information is available for the years 1980-2004 for nine main manufacturing sectors included in the database. For the panel starting in the 1970s, additional information is available from the World Trade Flows database (Feenstra et al. 2005), which provides bilateral trade data at the four-digit level. ${ }^{14}$ The data are aggregated to match the country- and industry-dimension of the remaining data. As the STAN-database, these data include information for manufacturing sectors only.

Political preferences: To measure how political and societal preferences affect the bargaining position of workers, two indicators are used. The first comes from the Database on Political Institutions compiled by the World Bank, which provides detailed information on the type of government or political system (Keefer 2007). From this database, a dummy variable (EXECRLC) is retrieved, which gives the main political orientation of the chief political executive (Right, Left, Center). If the general political environment affects the allocation of income between capital and labor, one would expect executives with a political orientation towards the left (right) to have a positive impact on the share of income going to labor

\footnotetext{
12 Total labor share and the share of employment by skill group have correlations of below 0.1 , hence multicolinearity is not an issue.

13 Empirical results in Bergin et al. (2007) show that labor income volatility in the US and Mexico is higher in outsourcing industries.

14 I am grateful to Julian di Giovanni and Andrei A. Levchenko for sharing their Stata code on industry concordances.
} 
(capital). Consequently, left-wing parties would be expected to smooth income for workers to a greater extent than right-wing parties. Dummies for left- and right-wing chief political executives are included, hence the coefficients must be interpreted relative to political executives coming from the center. Overall, the majority of observations is for right-wing governments (49\%), followed by left-wing (41\%), and centrist governments (10\%).

The second measure of political preferences is the top marginal income tax rate. This variable captures preferences towards redistributive policies. If political and societal preferences had an impact on firm-level bargaining, one would expect higher marginal income tax rates to be associated with a stronger bargaining power of workers. The expected sign is negative for the volatility of labor income. Of course, one could also argue for a positive expected sign if firms and workers consider a trade off between, on the one hand, firm- or industry-level insurance and, on the other hand, redistribution mechanisms and those provided by the tax and social security system.

Financial market development: The degree of development of financial markets should affect the willingness of capital owners to provide an implicit risk-sharing contract to workers. If financial markets are not very well developed, owners of capital cannot diversify risks and are less willing to bear risk than in a situation in which financial markets are well-developed. To capture this, the degree of stock market capitalization relative to GDP, as taken from the World Bank’s World Development Indicators, is included. The expected sign is positive for capital income and negative for labor income.

Volatility of TFP: The idiosyncratic volatility of total factor productivity (TFP) at the industry-level is used as a proxy of industry-specific developments. TFP volatility is computed in an analogous way to the volatility of labor and capital incomes. It should, according to the theoretical model, not affect the idiosyncratic volatility of labor incomes if implicit insurance contracts are effective. Shareholders, in contrast, insure consumption against idiosyncratic shocks by buying and selling financial assets. Their incomes derived from owning the capital stock of a particular industry, which are measured here, should fluctuate with idiosyncratic developments at the industry-level.

Unemployment insurance: Danthine and Donaldson (1989) argue that unemployment insurance can serve as a substitute for within-firm insurance mechanisms. The more generous unemployment insurance, the higher would be the expected volatility of labor income. The initial unemployment benefit replacement ratio and the period for which unemployment benefits are paid to are included as regressors account for this. More generous unemployment 
insurance as an alternative risk-sharing mechanism would make workers more willing to accept on-the-job risk. Hence, the expected sign is positive.

In addition, macroeconomic developments affecting all countries and sectors are captured through time fixed effects. To account for the specific circumstances of the German postreunification period, a dummy variable for this period is included. ${ }^{15}$

\subsection{Regression Results}

The variables described above are used to explain the absolute and relative volatilities of capital and labor income, Table 3 has the results for the absolute volatility of labor income, Table 4 presents results for the absolute volatility of capital income, and Table 5 has results for relative incomes.

According to Table 3, a higher volatility of TFP increases the absolute volatility of labor income (Columns 1-4). If insurance mechanisms inside the firms via implicit contracts would be fully operative, fluctuations in TFP should not affect labor incomes. One reason for the relative consistent positive effect of TFP fluctuations on labor income could be that some workers - in particular high-skilled workers - insure their consumption via participation in financial markets. For low-skilled workers, TFP volatility is insignificant, which is consistent with the presence of within-industry insurance mechanisms.

The two main measures for workers' bargaining power - country-wide union density and the industry-level labor share - are insignificant. Results for the third measure of bargaining power - the number of workers in a particular skill group - are interesting as they suggest that being numerous lowers the volatility of high-skilled and medium-skilled workers but not of low-skilled workers. Note that this variable also captures shifts in the relative demand for workers at different skill-levels. In this sense, the increased demand for workers with higher skill levels has been associated with a decline in the volatility of their incomes.

Unemployment insurance could serve as a substitute for implicit contracts within the firm, hence increasing the volatility of labor income. Results in fact show a positive and significant impact of the benefit replacement rate on labor income volatility. Results for the benefit duration depend on the specification. The effect is negative for high- and low-skilled workers

15 Although output volatility in Germany has been high in the immediate post-unification period (19901991), the corresponding dummy has a negative and significant sign. Hence, workers’ incomes have been shielded from the increase in output volatility. 
for the full sample and positive for all workers using the restricted (manufacturing) sample including measures for trade openness.

Results for the political variables show a positive impact of the chief political executive being from a left-wing party in two specifications. For high-skilled workers, this finding would be consistent with expectations, for low-skilled workers, in contrast, the expected sign would be negative. The dummy for the chief political executive officer being from a right-wing party is insignificant.

Columns 5-8 present results including stock market capitalization and trade openness. Greater openness for trade has no significant impact on the volatility of labor income. This finding would be in line with earlier work, which has difficulties tracing differences in the elasticity of labor demand to the degree of internationalization.

The impact of stock market capitalization on the volatility of labor income is positive for high-skilled and low-skilled workers. This has two possible interpretations. First, a more developed stock market provides greater possibilities to diversify risk, hence increasing the willingness of those (high-skilled) workers with access to the stock market to accept more volatile incomes. Second, high-skilled workers' remuneration might be directly tight to the performance of the stock market via stock options and other forms of bonus payments, hence increasing the volatility of their incomes. This explanation would be incompatible with the positive impact of stock market capitalization on the income volatility of low-skilled workers though.

Table 4 presents different specifications for the absolute volatility of capital income, using overlapping measures of volatility as before. In addition, results using squared residuals and non-overlapping observations for each 5-year period (quasi-panel) are reported as robustness checks.

There are three main results which are consistent across specifications. First, higher volatility of TFP increases the volatility of capital income, and the coefficient estimates are higher than those estimated for labor incomes. In line with the theoretical model, capital income thus reflects idiosyncratic industry-level volatility to a greater degree than labor incomes do. Second, a higher labor share in an industry increases the volatility of capital income. This is consistent with the theoretical model as well. Third, a higher benefit replacement rate increases the volatility of capital income, and the point estimate is higher than the one for labor income. This finding is at odds with expectations as more generous unemployment insurance provides an alternative to within-firm insurance mechanisms. Hence, the expected 
sign for capital income volatility would be negative. The remaining variables are insignificant, except for a weakly significant positive impact of the chief political executive being from a right-wing party.

Table 5 brings these two sets of results together and uses the ratio of the volatility of labor and capital income as the dependent variable. Consistent with the theoretical model, higher volatility of TFP lowers the volatility of labor incomes relative to that of capital income. Yet, this variable is significant only for high-skilled workers and - in one specification - for lowskilled workers.

Bargaining power has a significant impact on relative volatilities, consistent with the findings in Tables 3 and 4. The labor share has a negative sign, and it is significant in most specifications. Higher union density lowers the relative volatility of labor income as well. When restricting the sample to the manufacturing industries (Columns (2), (4), (6), and (8)), however, union density tends to become insignificant. For high- and medium-skilled workers, there is evidence that the share of these workers in the total labor force lowers the relative volatilities of their incomes. Being more numerous does not benefit the low-skilled workers though - the relative volatility of their labor incomes even increases in the share of lowskilled workers in the labor force. Finally, the benefit replacement ratio and benefit duration are negative and significant in some specifications. This would be consistent with more generous unemployment insurance as a measure of union power. It would be inconsistent with more generous unemployment insurance acting as an alternative insurance mechanism. If this was the case, these variables should have a positive sign.

Results for the political dummies support earlier findings but are not necessarily in line with expectations. If the chief political officer comes from a left-wing party, relative labor income volatility tends to be higher than in the base scenario of the executive being from the center. The dummy for political executives from right-wing parties, there are some positive coefficients. However, these results are not strong.

A more developed stock market increases rather than decreases the relative volatility of labor incomes. The variables measuring export and import openness are insignificant. In sum, these findings support the mechanism stressed in the theoretical model in the sense that capital income is more sensitive to industry-specific developments than labor income. Also, a greater bargaining power of workers lowers the relative volatility of labor income. 


\subsection{Robustness}

To check the robustness of the results, several modifications of the baseline model have been tested. Individual countries have been dropped successively, time-varying sector fixed effects have been included as regressors, the squared residual instead of volatility computed over a five years window has been used as the dependent variable, and the model has been estimated using a quasi-panel of non-overlapping windows for the period 1975-2000. The following results are not reported but are available upon request.

Drop countries: Dropping individual countries to check whether results are driven by a particular country shows that the results for the baseline specification of relative labor income volatility (Column 1 of Table 5) are quite robust. In particular, higher union density - as a measure of the bargaining power of workers in a given country - and a higher labor share - as a measure of bargaining power in a given industry - lower relative labor income volatility.

Sector-year fixed effects: A full set of sector-year fixed effects have been included to check whether any of the explanatory variables might capture omitted time-varying effects at the sector-level. ${ }^{16}$ Different trends in the offshorability of production and other shifts in industry structures could be captured by these variables. While the sector-year fixed effects cannot be interpreted in any meaningful way, including them allows testing for the robustness of the remaining results. Again, union density and the labor share generally retain their negative and significant signs.

Squared residuals: To check the robustness of the results, the squared residuals are used as a measure of volatility. This measure has the advantage that it does not require the choice of a particular time window to compute volatilities. Its disadvantage is that it has a more erratic time-series behavior and thus generates extreme values of relative volatilities. For this reason, the squared residuals have not been used to compute relative volatilities. Using squared residuals of labor income growth as the dependent variable supports most of the qualitative results reported in Table 3. In particular results for unemployment insurance and the employment shares by skill level are very similar.

Quasi-panel: Results for the quasi-panel confirm a couple of results concerning the determinants of the absolute volatility of labor income reported in Table 3. The degree of

\footnotetext{
16 A similar argument applies to country-year fixed effects. However, since some of the explanatory
} variables vary only at the country-level, including country-time fixed effects would imply that the effects of these variables cannot be measured anymore. 
unionization and the shares of high- and medium-skilled workers have a negative impact, as expected. Stock market capitalization has a positive impact, as before. Using the quasi-panel for relative volatility, the main qualitative results reported in Table 5 are confirmed as well. The labor share in particular is negative and significant. Shifting the start of the quasi-panel year-by-year gives the most robust results the labor share and union density (both negative) and the dummy for the political left (positive).

Industry-level unionization: For the US, time-varying information on union membership and coverage by industry is available. ${ }^{17}$ Neither the degree of coverage of union nor the share of union members in total employment has a significant impact on absolute or relative volatilities though. This mirrors the finding of Gottschalk and Moffit (1994) who find little impact of the degree of unionization on the volatility of earnings at the individual level. Hence, the results for union density are driven by the cross-country variation in the data. System of equations: According to the theoretical model, the volatility of labor and capital incomes is the result of an optimization problem at the firm-level, and these variables are simultaneously determined. To account for this, I have re-estimated the model using a seemingly related regressions model. The institutional arrangements of the unemployment insurance system have been used to identify the equation specifying labor income volatility. Results confirm earlier findings. These results are also used to test whether the impact of the explanatory variables on labor and capital income volatility differs significantly. This is strongly supported. Labor income volatility reacts less to volatility of TFP than the volatility of capital income. It is also lower the higher is union density. The labor share has a positive and significant impact on the volatility of labor income for medium-skilled workers, but the coefficient estimate is significantly smaller than the one for capital income. Hence, the net effect of an increase in the labor share is to lower the relative volatility of labor income. Age of workers: To test the prediction of the model by Danthine and Donaldson (1989) that the income of young (low-skilled) workers should be more volatile than the income of old (high-skilled) workers, the age of the workforce is included. However, results do not support the predictions of the model. Instead, a higher share of younger workers (below the age of 29 years) often lowered the volatility of labor income while a higher share of older workers (above the age of 50 years) in some specifications increased the volatility of labor income. 
Top marginal income tax rate: As expected, the top marginal income tax rate has a negative impact on the relative volatility of labor income, in particular for low- and medium-skilled workers. This would be consistent with higher marginal tax rates reflecting a positive societal attitude towards income stability for low-skilled workers.

Technological progress: Technological progress could increase the volatility of earnings if it leads to a faster depreciation of human capital and makes "more workers like new workers" (Katz 1994). To account for this, the log of ICT capital per worker is included. The impact is generally negative, in particular for relative volatilities. Hence, the stability of labor income has decreased rather than increased due to the increased use of ICT capital.

Wages versus employment: Results so far have looked at total labor income, not allowing for different responses of employment and wages. As a further robustness tests, I have reestimated the determinants of labor income volatility separately. Splitting labor income into the two components wages and employment (hours worked) shows similar results for TFP volatility (positive), the replacement ratio (positive), and benefit duration (negative). The impact of union density is insignificant. The results for employment shares (negative for highand medium-skilled, positive for low-skilled) are driven by adjustments of wage and employment volatility.

Panel 2 versus Panel 1: Finally, the model has been re-estimated using the long and narrow panel starting in the 1970s for four countries rather than the wide and short panel starting in the 1980s. By and large, the results are similar although, of course, there is much less crosssectional variation in some of the explanatory variables. The most consistent result is a negative impact of the labor share on the relative volatility of labor income.

\section{Summary}

Output volatility has declined in industrialized countries but there has been a concern that the volatility of labor incomes could have increased. This paper has analyzed whether there has been a "risk shift" from capital to labor in the sense that the relative volatility of labor incomes has increased. To answer this question, the paper uses an industry-level database for industrialized countries and the past 35 years.

Descriptive statistics show a decline in the unconditional volatility of labor and capital income growth, mirroring the Great Moderation of output volatility. When accounting for overall 
macroeconomic developments and isolating the idiosyncratic component of income growth, industry-level volatility does not show any strong time trend though.

In terms of the relative volatility between labor and capital, the paper shows heterogeneity across industries and countries. On average, the relative volatility of labor income has not changed much between the 1980s and 1990s. The same holds for incomes of workers with medium skill levels. There is, at the same time, evidence suggesting that the relative volatility of incomes of low-skilled workers has increased in some industries and countries.

To motivate an empirical analysis of the determinants of income volatility, a real business cycle model with redistributive shocks has been used. The model assumes that workers and owners of the capital stock enter into an implicit contract which insures workers against idiosyncratic shocks. Hence, workers smooth consumption even though they to not participate in financial markets. The model predicts that capital income responds more to idiosyncratic volatility than labor income. Moreover, a decline in the bargaining power of workers increases the relative volatility of labor income.

Empirical results explaining volatilities of capital and labor income support the mechanisms stressed in the theoretical model. Capital income volatility is more sensitive to sector-specific developments than labor income volatility. A greater bargaining power of workers lowers the relative volatility of labor income. Differences in trade openness across sectors do not have a significant impact on income volatilities. More developed stock markets, in contrast, tend to increase the relative volatility of labor incomes.

In future work, it would be interesting to analyze relative income volatilities using firm-level data. The theoretical model used here assumes income (and consumption) smoothing within the context of employment relationship within a given firm. It assumes lifetime employment relationship, and workers are willing to accept wages below marginal productivity in exchange for income insurance. If job market turnover increases, such mechanisms presumably become more difficult to maintain, thus affecting risk sharing between capital and labor. 


\section{Literature}

Bassanini, A., and R. Duval (2006). Employment Patterns in OECD Countries: Reassessing the Role of Policies and Institutions. OECD Economics Department Working Paper 486. Paris

Benati, L., and Surico, P. (2008). VAR Analysis and the Great Moderation. European Central Bank. ECB Working Paper 866. Frankfurt a.M.

Bergin, P.R., R.C. Feenstra, and G.H. Hanson (2007). Outsourcing and Volatility. National Bureau of Economic Research (NBER). Working Paper 13144. Cambridge, MA.

Blanchard, O.J. and Simon, J.A. (2001). The Long and Large Decline in U.S. Output Volatility. Brookings Papers on Economic Activity: 165-173.

Blundell, R., L. Pistaferri, and I. Preston (2008). Consumption Inequality and Partial Insurance. American Economic Review (forthcoming)

Bottazzi, L., P. Pesenti, and E. van Wincoop (1996). Wages, profits and the international portfolio puzzle. European Economic Review 40: 219-254.

Braun, M., and B. Larrain (2005). Finance and the Business Cycle: International, InterIndustry Evidence. Journal of Finance 60(3): 1097-1128.

Comin, D., E.L. Groshen, B. Rabin (2006). Turbulent Firms, Turbulent Wages? National Bureau of Economic Research. NBER Working Paper 12032. Cambridge MA.

Danthine, J.-P., and J.B. Donaldson (1989). Risk Sharing, the Minimum Wage, and the Business Cycle. In: W.A. Barnett, B. Cornet, C. d'Aspremont, J. Gabszewicz and A. Mas-Colell (eds). Equilibrium Theory and Applications, Proceedings of the Sixth International Symposium in Economic Theory and Econometrics, Chapter 13, Cambridge: Cambridge University Press: 299-318.

Danthine, J.-P., J. B. Donaldson, and P. Siconolfi (2008). Distribution Risk and Equity Returns. In: Handbook of the Equity Risk Premium. Elsevier (North Holland).

Davis, S.J., and J.A. Kahn (2007). Changes in the Volatility of Economic Activity at the Macro and Micro Levels. University of Chicago, Stern School, and NBER. Mimeo.

Deutsches Institut für Wirtschaftsforschung (DIW) (2007). Vermögen in Deutschland wesentlich ungleicher verteilt als Einkommen. DIW Wochenbericht 74(45): 665-672.

Dew-Becker, I., and R.J. Gordon (2008). The Role of Labor Market Changes in the Slowdown of European Productivity Growth. National Bureau of Economic Research. NBER Working Paper 13840. Cambridge MA.

Di Giovanni, J, and A.A. Levchenko (2008). Trade Openness and Volatility. Review of Economics and Statistics (forthcoming) 
Feenstra, R.C., R.E. Lipsey, H. Deng, A. C. Ma, and H. Mo (2005). World Trade Flows: 1962-2000. National Bureau of Economic Research. NBER Working Paper 11040. Cambridge MA.

Giannone, D., M. Lenza, and L. Reichlin (2007). Explaining The Great Moderation: It Is Not The Shocks. CEPR Discussion Paper 6600. London.

Gorbachev, O. (2007). Did Household Consumption Become More Volatile? Department of Economics, Columbia University. Mimeo.

Gottschalk, P., and R. Moffitt (1994). The Growth of Earnings Instability in the U.S. Labor Market. Brookings Papers on Economic Activity 2: 217-272.

Gürtzgen, N. (2005). Rent-Sharing and Collrective Bargaining Coverage - Evidence from Linked Employer-Employee Data. Centre for European Economic Research (ZEW). Discussion Paper 05-90. Mannheim.

Hacker, J.S. (2006). The Great Risk Shift. Oxford: Oxford University Press.

Harrison, A.E. (2002). Has Globalization Eroded Labor's Share? Some Cross-Country Evidence. UC Berkeley and NBER. Mimeo.

Jensen, J.B., and L.G. Kletzer (2007). Measuring Tradable Services and the Task Content of Offshorable Services Jobs. Georgetown University and the University of California, Santa Cruz. Mimeo.

Jensen, S.T., and S.H. Shore (2008). Changes in the Distribution of Income Volatility. Wharton School and Johns Hopkins University. Mimeo.

Katz, L. (1994). Comment on: Gottschalk, P., and R. Moffitt. The Growth of Earnings Instability in the U.S. Labor Market. Brookings Papers on Economic Activity 2: 255261.

Keefer, P. (2007). DPI2006 Database of Political Institutions: Changes and Variable Definitions. World Bank. Development Research Group.

Kose, M.A., E. Prasad, and M. Terrones (2007). How Does Financial Globalization Affect Risk Sharing? Patterns and Channels," IMF Working Papers 07/238, International Monetary Fund.

Lusardi, A., O.S. Mitchell (2007). Baby Boomer retirement security: The roles of planning, financial literacy, and housing wealth. Journal of Monetary Economics 54: 205-224.

Mankiw, N.G., and S.P. Zeldes (1990). The Consumption of Stockholders and NonStockholders. National Bureau of Economic Research. Working Paper 3402. Cambridge, MA.

Nickell, S. and S. Wadhwani (1990). Insider forces and wage determination. Economic Journal 100: 496-509.

Organisation for Economic Co-Operation and Development (OECD) (2007). OECD Employment Outlook. Chapter 3: OECD Workers in the Global Economy: Increasingly Vulnerable? Paris: 105-155. 
Pesaran, M.H. (2006). Estimation and Inference in Large Heterogeneous Panels with Multifactor Error Structure. Econometrica 74(4): 967-1012.

Scheve, K., and M.J. Slaughter, 2004. Economic Insecurity and the Globalization of Production. American Journal of Political Science 48(4), 662-674.

Shin, D., and G. Solon (2008). Trends in Mean's Earnings Volatility: What Does the Panel Study of Income Dynamics Show? National Bureau of Economic Research. NBER Working Paper 14075. Cambridge, MA.

Stock, J.H., and M.W. Watson (2002). Has the Business Cycle Changed and Why? In: Gertler, M., and K. Rogoff (eds.). NBER Macroeconomics Annual 2002. MIT Press. Cambridge MA 


\section{Data Appendix}

The main data source is EU KLEMS. All data are freely available on the internet and can be downloaded from www.euklems.net. The version of March 2007 is used. See Timmer et al. (2007) for details on the data definitions and original sources.

Real capital compensation (CAP): Nominal values were converted into constant US-Dollar by (i) converting values in national currency into US-Dollar using the Summers-Heston exchange rate series, adjusting for Euro conversion rates, and (ii) deflating by the US output price index in each sector. In addition to the outlier correction applied to all time series, the following cross-sections with incomplete data and recurring large changes were dropped: Finland - industries 20,F, H, N; Germany - 20, C, H; Netherlands - 30t33; all - 34t35; Austria - 36t37, N; Denmark - F; United Kingdom - F, J; France - M; Italy - M

Labor compensation $(L A B)$ : labor compensation by skill level is obtained by multiplying total labor compensation $(L A B)$ by the share of employment at each skill level in total labor compensation, i.e. (LABHS / 100) * LAB for high-skilled workers. Nominal values were converted into constant US-Dollar by (i) converting values in national currency into USDollar using the Summers-Heston exchange rate series, adjusting for Euro conversion rates, and (ii) deflating by the US output price index in each sector.

Total Factor Productivity (TFPva_I): TFP growth, both value-added and output-based. Output per hour growth minus capital deepening growth (= real capital growth - growth in total hours worked * capital's share in output)

Output (GO): Nominal values were converted into constant US-Dollar by(i) converting values in national currency into US-Dollar using the Summers-Heston exchange rate series, adjusting for Euro conversion rates, and (ii) deflating by the US output price index in each sector.

Trade: (i) OECD Stan: Data on import-export ratios, the export share of production, and the import penetration ratio by industry, 1980-2004, for the following manufacturing sectors: Food, Textiles, Wood, Pulp \& Paper, Chemicals, Non-metallic mineral products, Based metals, Machinery, Transport equipment, (ii) World Trade Flows: Data on bilateral import volumes obtained from Feenstra et al. (2005). SITC4 industry classification codes were converted into ISIC codes (Version 3) using industry concordances kindly provided by Julian di Giovanni and used in di Giovanni and Levchenko (2008). For the years before 1990, we use West German data to match the data to EUKLEMS.

List of countries: The EU KLEMS database contains information on 27 countries in Europe plus Japan and the United States. However, due to incomplete time series and missing observations, in particular concerning a breakdown of employment by skill, we use only the following 11 countries:

AUT $=$ Austria, DNK = Denmark, ESP $=$ Spain, FIN = Finland, FRA = France, GER = Germany ITA = Italy, JPN = Japan, NLD = Netherlands, UK = United Kingdom, USA = United States-SIC based

List of industries: The EU KLEMS database contains industry-level data at different levels of aggregation. We use data at the 2-digit level, and we drop the sectors agriculture, fishing, and extra-territorial organizations due to missing and incomplete observations. Hence, we use data for the following sectors (sector codes based on NACE):

$15 t 16$ = Food, Beverages and Tobacco; 17t19 = Textiles, Leather, and Footwear; 20 = Wood, products of wood, and cork; 21t22 = Pulp, paper, printing and publishing; 23t25 = Chemicals, 
rubber, plastic, and fuels; $\mathbf{2 6}=$ Other non-metallic mineral products; $\mathbf{2 7} \mathbf{2 8}=$ Basic metals and fabricated metals; 29 = Machinery nec.; 30t33 = Electrical and optimal equipment; 34t35 = Transport equipment; $\boldsymbol{C}=$ Mining and quarrying; $\boldsymbol{E}=$ Electricity, gas, and water supply; $\boldsymbol{F}=$ Construction; $\boldsymbol{G}=$ wholesale and retail trade; $\boldsymbol{H}=$ Hotels and restaurants; $\boldsymbol{I}=$ Transport, storage, and communications; $\boldsymbol{J}=$ Financial intermediation, $\boldsymbol{K}=$ Real estate, renting, and business activities; $\boldsymbol{L}=$ Public administration and defense, social security; $\boldsymbol{N}=$ Health and social work; $\boldsymbol{O}=$ Other services

In some countries, industry classifications have changed in the mid-1990s. Where available, the EUKLEMS database uses conversion tables provided by the national statistical offices. The change in the American classification system (from SIC87 to NAICS97) was more farreaching than of the most recent change in the European system.

German dummy: Dummy variable equal to one for the years 1990 and 1991 for Germany to capture the unification effect.

Labor market regulations: Data have been compiled by Bassanini and Duval (2006) and are available online. We use the following five indicators:

o Net union density: Share of workers affiliated with unions in \%

o Benefit replacement rates: percentage of average before tax earnings covered through unemployment and social insurance programs

o Benefit duration: duration of unemployment benefits

Stock market development: market value of shares traded relative to GDP (in \%), taken from the World Development Indicators (WDI) on CD-rom.

Political dummies: 0/1-dummies for the main political orientation of the chief political executive (left / right / center) taken from the Database on Political Institutions by the World Bank (Keefer 2007).

Marginal tax rates: Data on personal income top marginal tax rates in OECD countries for the years 1975-2005 are taken from the Tax Policy Center (http://www.taxpolicycenter.org/taxfacts/displayafact.cfm?Docid=477). Missing values for the individual year 1983 were ipolated for the following countries: Denmark, Italy, Japan, and Spain.

Inflation: Change in the price level of consumption (CP) is the PPP over GDP divided by the exchange rate times 100 . The PPP of GDP or any component is the national currency value divided by the real value in international dollars. The PPP and the exchange rate are both expressed as national currency units per US dollar. From Penn World Table 6.1 (PWT 6.1).

Energy prices index: HWWI-World energy price index US-Dollar based, 2000=100 


\section{Graph 1: Volatility of Labor and Capital Income}

The following graphs plot the median volatility of labor and capital income for 11 European countries, the US and Japan across 22 industries. Volatility is defined as the standard deviation of real income growth over a rolling 5-year window. Unconditional uses the growth rates of income; conditional uses the residuals of a regression of these growth rates on fixed effects and year dummies. For Graphs 1e-1g, conditional volatilities have been obtained using the multifactor residual model by Pesaran (2006) described in the main body of the text. Volatility in $t$ is defined for the subsequent period $[t, t+4]$.

(a) Volatility of labor income (“wide and short” panel, 1982-2002)



(b) Volatility of capital income (“wide and short” panel, 1982-2002)




(c) Relative conditional volatility (labor income / capital income) (“wide and short" panel, $\underline{1982-2002)}$


(d) Labor share and shares in labor income (by skill level) ("wide and short" panel, 1982$\underline{2002)}$
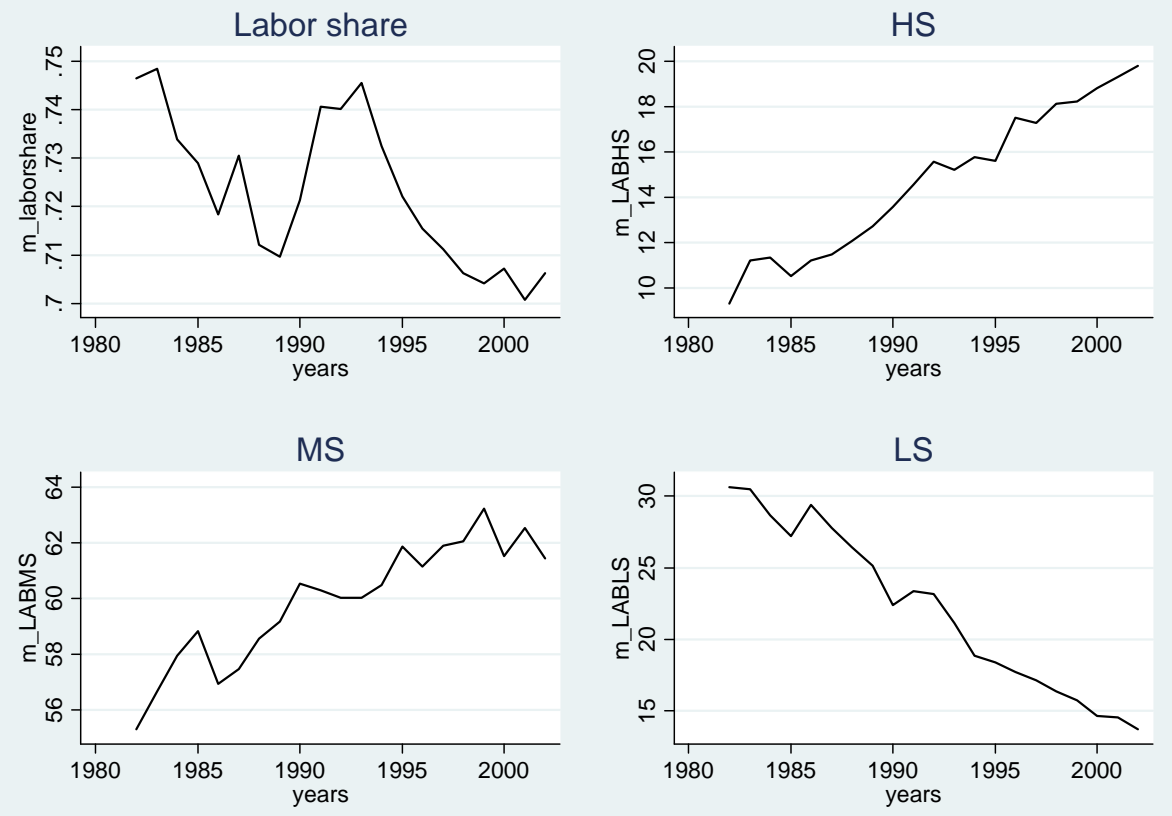
(e) Volatility of labor income ("long and narrow” panel, 1970-2004)


(f) Volatility of capital income ("long and narrow" panel, 1970-2004)

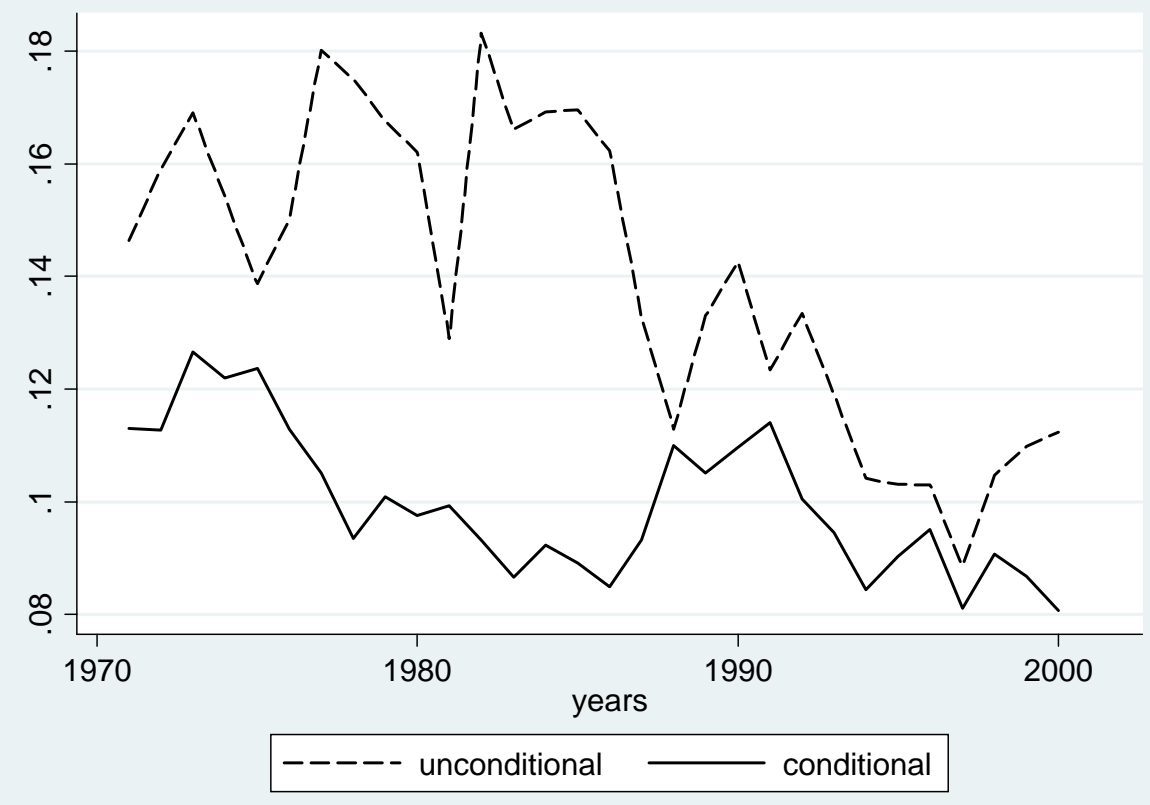


(g) Relative conditional volatility (labor income / capital income) ("long and narrow" panel, $\underline{1970-2004)}$
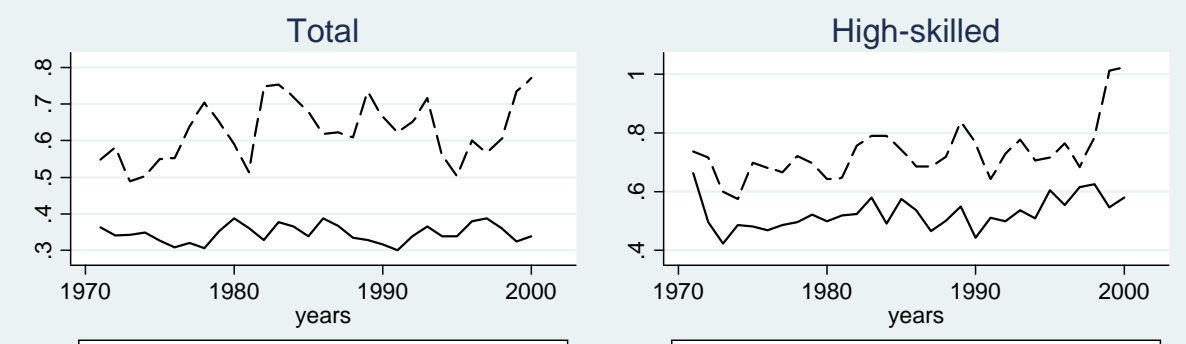

--- unconditional $\longrightarrow$ conditional

$---\cdot$ unconditional $\longrightarrow$ conditional

Table 1: Descriptive Statistics

\begin{tabular}{|c|c|c|c|c|c|}
\hline & Obs & Mean & Std. Dev. & Min & Max \\
\hline \multicolumn{6}{|l|}{ 5-year moving average conditional volatilities } \\
\hline Total labor income & 6,394 & 0.028 & 0.027 & 0.003 & 0.549 \\
\hline High-skilled income & 6,394 & 0.060 & 0.049 & 0.003 & 0.476 \\
\hline Medium-skilled income & 6,394 & 0.037 & 0.032 & 0.002 & 0.563 \\
\hline Low-skilled income & 6,394 & 0.050 & 0.044 & 0.002 & 0.591 \\
\hline Capital income & 6,350 & 0.019 & 0.027 & 0.001 & 1.405 \\
\hline Output & 6,284 & 0.034 & 0.026 & 0.003 & 0.274 \\
\hline TFP & 6,306 & 0.037 & 0.028 & 0.003 & 0.505 \\
\hline \multicolumn{6}{|l|}{ Relative conditional volatility (labor / capital income) } \\
\hline Total & 5,677 & 0.288 & 0.318 & 0.006 & 5.233 \\
\hline High-skilled & 5,677 & 0.657 & 0.732 & 0.013 & 16.140 \\
\hline Medium-skilled & 5,677 & 0.388 & 0.425 & 0.007 & 7.310 \\
\hline Low-skilled & 5,677 & 0.570 & 0.820 & 0.008 & 18.328 \\
\hline \multicolumn{6}{|l|}{ 5-year moving average unconditional volatilities } \\
\hline Total labor income & 6,394 & 0.111 & 0.053 & 0.006 & 0.740 \\
\hline High-skilled income & 6,394 & 0.128 & 0.062 & 0.007 & 0.688 \\
\hline Medium-skilled income & 6,394 & 0.115 & 0.054 & 0.006 & 0.747 \\
\hline Low-skilled income & 6,394 & 0.128 & 0.060 & 0.011 & 0.749 \\
\hline Capital income & 6,350 & 0.022 & 0.032 & 0.001 & 1.840 \\
\hline Output & 6,284 & 0.106 & 0.049 & 0.005 & 0.346 \\
\hline TFP & 6,306 & 0.042 & 0.034 & 0.002 & 0.622 \\
\hline \multicolumn{6}{|l|}{ Relative unconditional volatility (labor / capital income) } \\
\hline Total & 5,677 & 0.783 & 0.488 & 0.058 & 10.504 \\
\hline High-skilled & 5,677 & 0.945 & 0.676 & 0.053 & 10.592 \\
\hline Medium-skilled & 5,677 & 0.819 & 0.536 & 0.030 & 10.789 \\
\hline Low-skilled & 5,677 & 0.980 & 0.854 & 0.045 & 14.200 \\
\hline \multicolumn{6}{|l|}{ Shares in labor income } \\
\hline High-skilled & 7,709 & 0.127 & 0.128 & 0.002 & 0.831 \\
\hline Medium-skilled & 7,709 & 0.570 & 0.193 & 0.032 & 0.984 \\
\hline Low-skilled & 7,709 & 0.303 & 0.203 & 0.001 & 0.959 \\
\hline Labor share & 7,571 & 0.705 & 0.159 & 0.022 & 1.000 \\
\hline \multicolumn{6}{|l|}{ Labor market indicators } \\
\hline$\overline{\text { Initial unemployment benefit replacement rate (\%) }}$ & 5,698 & 0.455 & 0.198 & 0.010 & 0.875 \\
\hline Unemployment benefit duration (years) & 5,698 & 0.662 & 0.198 & 0.319 & 1.637 \\
\hline \multicolumn{6}{|l|}{ Political indicators } \\
\hline$\overline{\text { Left-wing governor }}$ & 7,709 & 0.378 & 0.485 & 0.000 & 1.000 \\
\hline Right-wing governor & 7,709 & 0.457 & 0.498 & 0.000 & 1.000 \\
\hline \multicolumn{6}{|l|}{ Openness and financial markets } \\
\hline Export share of production (\%) & 2,784 & 0.320 & 0.280 & 0.001 & 2.022 \\
\hline Import penetration (\%) & 2,800 & 0.343 & 0.294 & 0.001 & 1.977 \\
\hline Stock market capitalization (\% of GDP) & 4,471 & 0.479 & 0.545 & 0.012 & 3.263 \\
\hline Dummy for Germany $(1990,1991)$ & 7,709 & 0.005 & 0.074 & 0.000 & 1.000 \\
\hline
\end{tabular}




\section{Table 2: Tests on Differences in Means}

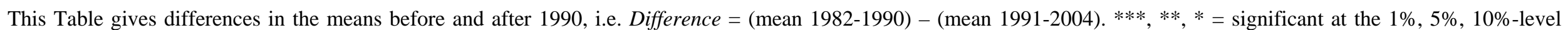

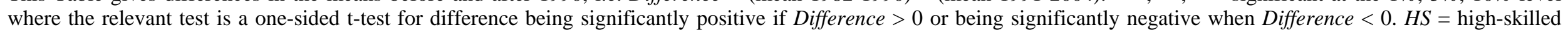
labor income, $M S$ = medium-skilled labor income, $L S=$ low-skilled labor income, Capital = capital income.

\section{(a) By sector}

\begin{tabular}{|c|c|c|c|c|c|c|c|c|c|}
\hline & \multicolumn{4}{|c|}{ Absolute volatilities } & \multicolumn{5}{|c|}{ Relative volatilities } \\
\hline & Total & HS & MS & LS & Total & HS & MS & LS & Capital \\
\hline Food & -0.013 & $0.009 *$ & 0.064 & $-0.135 * *$ & -0.001 & 0.001 & $0.005^{*}$ & $-0.007 * * *$ & -0.002 \\
\hline Textiles & 0.004 & 0.040 & $0.178 * *$ & -0.048 & -0.001 & $-0.016^{* *}$ & -0.001 & $-0.005 * *$ & 0.011 \\
\hline Wood & $0.118 * * *$ & -0.074 & $0.139 * * *$ & -0.013 & $0.007 * * *$ & -0.001 & $0.008^{* * *}$ & $-0.004^{*}$ & $0.044 * * *$ \\
\hline Pulp \& paper & $0.067 *$ & 0.070 & 0.026 & -0.056 & $0.004^{* *}$ & 0.003 & 0.001 & $-0.004^{*}$ & 0.005 \\
\hline Chemicals & -0.026 & $-0.138 * *$ & $-0.094 * *$ & $-0.127 *$ & -0.001 & $-0.008 * *$ & $-0.003 * *$ & -0.003 & $0.021 * * *$ \\
\hline Other metals & $0.118^{* * *}$ & -0.045 & $0.083^{* *}$ & -0.042 & $0.009 * * *$ & 0.0004 & $0.008^{* * *}$ & 0.001 & $0.011 *$ \\
\hline Basic metals & $0.093 * * *$ & 0.008 & $0.087 * * *$ & 0.025 & $0.004^{* * *}$ & $-0.007^{*}$ & $0.004^{* *}$ & -0.001 & -0.005 \\
\hline Machinery & $0.083^{*}$ & -0.024 & $0.094 *$ & -0.069 & $0.005^{* * *}$ & 0.0002 & $0.004^{* *}$ & $-0.001^{* *}$ & $0.019 *$ \\
\hline Electrical equipment & $0.100 * * *$ & $0.103^{* *}$ & $0.108^{* * *}$ & 0.064 & 0.001 & -0.004 & -0.001 & $-0.013 * * *$ & $-0.017^{*}$ \\
\hline Transport equipment & & & & & $0.004 *$ & 0.002 & 0.0001 & $-0.010 * *$ & \\
\hline Metals & $0.173 * * *$ & $0.432 * * *$ & $0.130 * * *$ & $0.132 * * *$ & $0.013 * * *$ & $0.015^{* *}$ & $0.006^{*}$ & 0.001 & $-0.092 * * *$ \\
\hline Mining & $0.213^{* *}$ & 0.020 & 0.064 & $-0.312 * *$ & $0.023^{* *}$ & $0.017 *$ & $0.017 *$ & $-0.033 * *$ & -0.007 \\
\hline Construction & -0.009 & $-0.665^{* * *}$ & 0.014 & $-0.301 * * *$ & $0.005^{* *}$ & $-0.025^{* * *}$ & $0.007 * * *$ & $-0.010 * * *$ & $0.033 * * *$ \\
\hline Trade & 0.014 & -0.176 & -0.029 & $-0.236 * * *$ & $0.004^{* * *}$ & $0.010 * * *$ & $0.004^{* *}$ & $-0.008 * * *$ & $0.027 * * *$ \\
\hline Hotels & $0.060 * * *$ & -0.019 & 0.013 & $-0.098 * *$ & $0.014 * * *$ & $0.027 * * *$ & $0.013^{* * *}$ & 0.002 & $0.033 * * *$ \\
\hline Transport \& comm. & -0.008 & $-0.147^{*}$ & -0.015 & $-0.262 * * *$ & $0.004^{* * *}$ & -0.003 & $0.005^{* * *}$ & $-0.013 * * *$ & $0.016^{* * *}$ \\
\hline Finance & 0.026 & 0.065 & $0.114^{* * *}$ & -0.153 & $0.004^{* *}$ & $0.013^{* *}$ & $0.010^{* * *}$ & $-0.013^{*}$ & $0.021 *$ \\
\hline Real estate etc. & $-0.218 * * *$ & $-0.202 * *$ & $-0.298 * * *$ & $-0.901 * * *$ & $0.002 *$ & $0.011 * * *$ & 0.001 & -0.002 & $0.049 * * *$ \\
\hline Public admin. & $-0.066 * * *$ & 0.118 & -0.001 & $-0.309 * *$ & 0.0003 & $0.018 * * *$ & $0.005^{* *}$ & 0.0001 & 0.009 \\
\hline Education & $0.077 * * *$ & $0.115^{* * *}$ & $0.168 * * *$ & $0.263^{* * *}$ & $0.0025^{* *}$ & 0.002 & 0.003 & -0.002 & $-0.077 * * *$ \\
\hline Health, social & -0.002 & $-0.227 * * *$ & $0.081 *$ & $-0.408 * * *$ & $0.003^{* *}$ & 0.002 & $0.012^{* * *}$ & -0.001 & 0.010 \\
\hline Other services & $0.045^{*}$ & -0.063 & 0.014 & $-0.158 * *$ & $0.008 * * *$ & 0.006 & $0.007 * * *$ & $-0.007^{*}$ & $0.021^{* * *}$ \\
\hline
\end{tabular}


(b) By country

\begin{tabular}{|c|c|c|c|c|c|c|c|c|c|}
\hline & \multicolumn{4}{|c|}{ Absolute volatilities } & \multicolumn{5}{|c|}{ Relative volatilities } \\
\hline & Total & HS & MS & LS & Total & HS & MS & LS & Capital \\
\hline Austria & -0.006 & $-0.443^{* * *}$ & $0.065^{* *}$ & -0.169 & $0.003 * * *$ & $-0.024 * * *$ & $0.007 * * *$ & $0.006^{*}$ & $0.012^{* *}$ \\
\hline Denmark & $0.035 * * *$ & $0.041^{*}$ & $0.032 * *$ & -0.001 & $0.010 * * *$ & $0.015 * * *$ & $0.009 * * *$ & $0.003^{*}$ & $0.025 * * *$ \\
\hline Spain & $0.134 * * *$ & 0.127 & $0.314 * * *$ & -0.008 & $0.013 * * *$ & $0.024 * * *$ & $0.029 * * *$ & 0.003 & $0.015^{* * *}$ \\
\hline Finland & -0.008 & -0.001 & -0.004 & -0.008 & $-0.002^{*}$ & -0.001 & $-0.004 * *$ & $-0.004 * *$ & -0.001 \\
\hline France & 0.003 & 0.091 & 0.001 & $-0.101^{* *}$ & -0.002 & 0.002 & -0.001 & $-0.014 * * *$ & -0.001 \\
\hline Germany & $0.057 * * *$ & 0.009 & $0.057 * * *$ & 0.002 & -0.001 & $-0.009 * * *$ & $-0.002 *$ & $-0.005 * * *$ & $-0.054 * * *$ \\
\hline Italy & $0.118 * * *$ & $0.138 * * *$ & $0.112^{* * *}$ & $0.099 * * *$ & $0.003^{* *}$ & $0.002 *$ & $0.003 * *$ & 0.001 & $-0.027 * *$ \\
\hline Japan & -0.011 & -0.024 & $-0.036^{* *}$ & $-0.211 * * *$ & $0.001^{*}$ & $0.008 * * *$ & -0.0001 & $-0.016 * * *$ & 0.018 \\
\hline Netherlands & $-0.057^{*}$ & $-0.431^{* * *}$ & $-0.191 * * *$ & $-1.17 * * *$ & $0.003 * * *$ & $-0.029 * * *$ & $-0.007 * * *$ & $-0.069 * * *$ & 0.006 \\
\hline United Kingdom & $0.110 * * *$ & $0.075^{*}$ & 0.046 & $-0.062 *$ & $0.022 * * *$ & $0.025 * * *$ & $0.018^{* * *}$ & $0.009 *$ & $0.026 * * *$ \\
\hline United States & $-0.106 * * *$ & $-0.356 * * *$ & $-0.160 * * *$ & $-0.523 * * *$ & $0.003^{*}$ & $-0.007 * *$ & $0.003^{*}$ & $-0.010 * * *$ & $0.027 * * *$ \\
\hline
\end{tabular}




\section{Table 3: Determinants of the Absolute Volatility of Labor Income}

The dependent variable is the volatility of conditional labor income growth, computed over a five-year moving window $[t, t+4]$. The explanatory variables are measured in $t$. standard errors have been adjusted for heterogeneity and autocorrelation of unknown form. $t$-values are reported in brackets. Fixed effects panel regressions with the cross-section dimensions being determined by the combination of 11 countries and 22 industrial sectors. $H S=$ high-skilled labor income, $M S=$ medium-skilled labor income, $L S=$ low-skilled labor income. Time fixed effects are included. $* * *, * *, *=$ significant at the $1 \%, 5 \%, 10 \%$-level.

\begin{tabular}{|c|c|c|c|c|c|c|c|c|}
\hline & $\begin{array}{c}(1) \\
\text { ALL } \\
\end{array}$ & $\begin{array}{l}\text { (2) } \\
\text { HS } \\
\end{array}$ & $\begin{array}{l}\text { MS) } \\
\text { MS }\end{array}$ & $\begin{array}{l}\text { (4) } \\
\text { LS }\end{array}$ & $\begin{array}{c}(5) \\
\text { ALL } \\
\end{array}$ & $\begin{array}{l}\text { (6) } \\
\text { HS } \\
\end{array}$ & $\begin{array}{l}7) \\
\text { MS }\end{array}$ & $\begin{array}{l}\text { (8) } \\
\text { LS }\end{array}$ \\
\hline TFP volatility & $\begin{array}{r}0.165^{* * *} \\
(3.26)\end{array}$ & $\begin{array}{r}0.190 * * \\
(2.28)\end{array}$ & $\begin{array}{r}0.176^{* * *} \\
(3.56)\end{array}$ & $\begin{array}{l}0.113 \\
(1.54)\end{array}$ & $\begin{array}{r}0.095^{* * *} \\
(3.28)\end{array}$ & $\begin{array}{l}0.111 \\
(1.40)\end{array}$ & $\begin{array}{r}0.118 * * \\
(2.45)\end{array}$ & $\begin{array}{l}0.022 \\
(0.45)\end{array}$ \\
\hline Benefit replacement rate & $\begin{array}{r}0.031^{* * *} \\
(3.75)\end{array}$ & $\begin{array}{r}0.054 * * * \\
(4.33)\end{array}$ & $\begin{array}{r}0.030 * * * \\
(3.68)\end{array}$ & $\begin{array}{l}0.008 \\
(0.93)\end{array}$ & $\begin{array}{r}0.023^{* * *} \\
(2.74)\end{array}$ & $\begin{array}{r}0.032 * \\
(1.87)\end{array}$ & $\begin{array}{r}0.018 \\
(1.64)\end{array}$ & $\begin{array}{r}-0.002 \\
(0.16)\end{array}$ \\
\hline Benefit duration & $\begin{array}{l}0.003 \\
(0.99)\end{array}$ & $\begin{array}{r}-0.014^{* *} \\
(2.46)\end{array}$ & $\begin{array}{r}-0.002 \\
(0.79)\end{array}$ & $\begin{array}{r}-0.019 * * * \\
(3.75)\end{array}$ & $\begin{array}{r}0.009 * * \\
(2.54)\end{array}$ & $\begin{array}{r}-0.001 \\
(0.11)\end{array}$ & $\begin{array}{l}0.006 \\
(1.54)\end{array}$ & $\begin{array}{r}-0.007 \\
(1.21)\end{array}$ \\
\hline Union density & $\begin{array}{l}0.019 \\
(0.59)\end{array}$ & $\begin{array}{l}-0.05 \\
(0.89)\end{array}$ & $\begin{array}{r}-0.011 \\
(0.29)\end{array}$ & $\begin{array}{r}0.054 \\
(1.29)\end{array}$ & $\begin{array}{l}-0.02 \\
(0.59)\end{array}$ & $\begin{array}{r}-0.054 \\
(0.83)\end{array}$ & $\begin{array}{r}-0.047 \\
(0.96)\end{array}$ & $\begin{array}{l}-0.03 \\
(0.70)\end{array}$ \\
\hline Political left (0/1) & $\begin{array}{l}0.002 \\
(0.95)\end{array}$ & $\begin{array}{r}0.009 * * * \\
(3.29)\end{array}$ & $\begin{array}{r}-0.001 \\
(0.36)\end{array}$ & $\begin{array}{r}0.009 * * * \\
(3.88)\end{array}$ & $\begin{array}{r}-0.004 \\
(1.29)\end{array}$ & $\begin{array}{l}0.005 \\
(1.17)\end{array}$ & $\begin{array}{r}-0.002 \\
(0.47)\end{array}$ & $\begin{array}{l}0.003 \\
(0.87)\end{array}$ \\
\hline Political right $(0 / 1)$ & $\begin{array}{l}0.001 \\
(0.39)\end{array}$ & $\begin{array}{l}0.003 \\
(1.01)\end{array}$ & $\begin{array}{r}-0.004 \\
(1.44)\end{array}$ & $\begin{array}{r}0.005^{*} \\
(1.70)\end{array}$ & $\begin{array}{r}-0.004 \\
(1.41)\end{array}$ & $\begin{array}{r}0 \\
(0.03)\end{array}$ & $\begin{array}{r}-0.005 \\
(1.25)\end{array}$ & $\begin{array}{r}0 \\
(0.15)\end{array}$ \\
\hline Labor share (\%) & $\begin{array}{r}-0.008 \\
(0.42)\end{array}$ & $\begin{array}{r}-0.007 \\
(0.27)\end{array}$ & $\begin{array}{r}-0.007 \\
(0.32)\end{array}$ & $\begin{array}{r}-0.014 \\
(0.63)\end{array}$ & $\begin{array}{r}-0.016 \\
(1.62)\end{array}$ & $\begin{array}{r}0.008 \\
(0.30)\end{array}$ & $\begin{array}{r}-0.028 \\
(1.37)\end{array}$ & $\begin{array}{l}0.008 \\
(0.49)\end{array}$ \\
\hline Share high-skilled & & $\begin{array}{r}-0.214 * * \\
(2.12)\end{array}$ & & & & $\begin{array}{r}-0.324^{*} \\
(1.78)\end{array}$ & & \\
\hline Share medium-skilled & & & $\begin{array}{r}-0.093 * * * \\
(2.70)\end{array}$ & & & & $\begin{array}{r}-0.086^{* *} \\
(2.47)\end{array}$ & \\
\hline Share low-skilled & & & & $\begin{array}{r}0.160^{* * * *} \\
(3.01)\end{array}$ & & & & $\begin{array}{r}0.161^{* * *} \\
(2.68)\end{array}$ \\
\hline Export share & & & & & $\begin{array}{r}-0.021 \\
(1.20)\end{array}$ & $\begin{array}{r}0.058 \\
(0.88)\end{array}$ & $\begin{array}{r}-0.012 \\
(0.49)\end{array}$ & $\begin{array}{r}-0.022 \\
(0.76)\end{array}$ \\
\hline Import penetration & & & & & $\begin{array}{l}0.007 \\
(0.31)\end{array}$ & $\begin{array}{l}-0.01 \\
(0.12)\end{array}$ & $\begin{array}{r}-0.002 \\
(0.09)\end{array}$ & $\begin{array}{l}0.025 \\
(0.76)\end{array}$ \\
\hline Stock market capitalization & & & & & $\begin{array}{l}0.002 \\
(0.79)\end{array}$ & $\begin{array}{r}0.016^{* *} \\
(2.38)\end{array}$ & $\begin{array}{l}0.002 \\
(0.65)\end{array}$ & $\begin{array}{r}0.012 * * * \\
(3.93)\end{array}$ \\
\hline Dummy Germany (0/1) & $\begin{array}{r}0 \\
(0.18)\end{array}$ & $\begin{array}{r}-0.010 * \\
(1.94)\end{array}$ & $\begin{array}{r}-0.003 \\
(1.03)\end{array}$ & $\begin{array}{r}0.002 \\
(0.71)\end{array}$ & $\begin{array}{r}-0.002 \\
(0.52)\end{array}$ & $\begin{array}{r}-0.016^{* * *} \\
(3.40)\end{array}$ & $\begin{array}{r}-0.004 \\
(0.82)\end{array}$ & $\begin{array}{r}0.009 * * \\
(2.14)\end{array}$ \\
\hline Constant & $\begin{array}{r}0.008 \\
(0.66)\end{array}$ & $\begin{array}{r}0.088 * * * \\
(3.25)\end{array}$ & $\begin{array}{r}0.084^{* * *} \\
(4.19)\end{array}$ & $\begin{array}{r}-0.028 \\
(1.00)\end{array}$ & $\begin{array}{r}0.026 \\
(1.64)\end{array}$ & $\begin{array}{r}0.055 \\
(1.52)\end{array}$ & $\begin{array}{r}0.107 * * * \\
(3.83)\end{array}$ & $\begin{array}{r}-0.001 \\
(0.02)\end{array}$ \\
\hline Observations $(N * T)$ & 4,682 & 4,682 & 4,682 & 4,682 & 1,547 & 1,547 & 1,547 & 1,547 \\
\hline Cross-sections $(N)$ & 263 & 263 & 263 & 263 & 129 & 129 & 129 & 129 \\
\hline$R^{2}$ & 0.08 & 0.05 & 0.11 & 0.07 & 0.11 & 0.1 & 0.13 & 0.11 \\
\hline
\end{tabular}




\section{Table 4: Determinants of the Absolute Volatility of Capital Income}

The dependent variable in columns (1) and (2) is the volatility of conditional capital income, computed over a five-year moving window ( $t, t+4)$. In Columns (3) and (4), a quasi-panel of non-overlapping 5-year windows is used. In Columns (5) and (6), a squared residual growth rate is used as a measure of volatility. The explanatory variables are measured in $t$. standard errors have been adjusted for heterogeneity and autocorrelation of unknown form. $t$-values are reported in brackets. Fixed effects panel regressions with the cross-section dimensions being determined by the combination of 11 countries and 22 industrial sectors. Time fixed effects are included. ***, $* *, *=$ significant at the $1 \%, 5 \%, 10 \%$-level.

\begin{tabular}{|c|c|c|c|c|c|c|}
\hline & $\begin{array}{c}(1) \\
5 \text {-year } \\
\text { moving } \\
\text { window }\end{array}$ & $\begin{array}{c}(2) \\
5-y e a r \\
\text { moving } \\
\text { window }\end{array}$ & $\begin{array}{c}\text { (3) } \\
\text { Quasi- } \\
\text { panel }\end{array}$ & $\begin{array}{c}(4) \\
\text { Quasi- } \\
\text { panel }\end{array}$ & $\begin{array}{c}(5) \\
\text { Squared } \\
\text { residual }\end{array}$ & $\begin{array}{c}(6) \\
\text { Squared } \\
\text { residual }\end{array}$ \\
\hline TFP volatility & $\begin{array}{r}0.901^{* * * *} \\
(5.51)\end{array}$ & $\begin{array}{r}0.800 * * * \\
(2.63)\end{array}$ & $\begin{array}{r}0.825^{* * * *} \\
(4.83)\end{array}$ & $\begin{array}{r}1.069 * * * \\
(3.13)\end{array}$ & $\begin{array}{r}2.092 * * * \\
(2.74)\end{array}$ & $\begin{array}{r}3.445^{* *} \\
(2.30)\end{array}$ \\
\hline Benefit replacement rate & $\begin{array}{r}0.077 * * \\
(2.01)\end{array}$ & $\begin{array}{r}0.097 * * \\
(2.23)\end{array}$ & $\begin{array}{r}0.085 \\
(1.15)\end{array}$ & $\begin{array}{r}0.127 * \\
(1.96)\end{array}$ & $\begin{array}{r}0.036 * * \\
(2.36)\end{array}$ & $\begin{array}{r}0.027 * * \\
(2.08)\end{array}$ \\
\hline Benefit duration & $\begin{array}{r}0.01 \\
(0.32)\end{array}$ & $\begin{array}{r}-0.019 \\
(0.71)\end{array}$ & $\begin{array}{r}-0.027 \\
(0.67)\end{array}$ & $\begin{array}{r}-0.073 \\
(1.05)\end{array}$ & $\begin{array}{l}0.029 \\
(0.70)\end{array}$ & $\begin{array}{r}-0.004 \\
(0.42)\end{array}$ \\
\hline Union density & $\begin{array}{r}0.051 \\
(0.71)\end{array}$ & $\begin{array}{r}-0.319 \\
(1.05)\end{array}$ & $\begin{array}{l}0.145 \\
(1.27)\end{array}$ & $\begin{array}{r}-0.207 \\
(0.65)\end{array}$ & $\begin{array}{r}-0.002 \\
(0.05)\end{array}$ & $\begin{array}{r}-0.058 \\
(0.73)\end{array}$ \\
\hline Labor share (\%) & $\begin{array}{r}0.329 * * * \\
(4.91)\end{array}$ & $\begin{array}{r}0.306 * * \\
(2.29)\end{array}$ & $\begin{array}{r}0.435^{* * * *} \\
(5.02)\end{array}$ & $\begin{array}{r}0.312 * * \\
(2.10)\end{array}$ & $\begin{array}{r}0.212 * * * \\
(4.63)\end{array}$ & $\begin{array}{r}0.130 * \\
(1.95)\end{array}$ \\
\hline Political left (0/1) & $\begin{array}{l}0.012 \\
(0.78)\end{array}$ & $\begin{array}{r}0.058 \\
(1.60)\end{array}$ & $\begin{array}{r}0.052 \\
(1.62)\end{array}$ & $\begin{array}{r}0.114^{*} \\
(1.68)\end{array}$ & $\begin{array}{r}-0.015 \\
(1.14)\end{array}$ & $\begin{array}{l}0.007 \\
(0.55)\end{array}$ \\
\hline Political right $(0 / 1)$ & $\begin{array}{l}0.021 \\
(1.18)\end{array}$ & $\begin{array}{r}0.062 * \\
(1.66)\end{array}$ & $\begin{array}{c}0.063^{*} \\
(1.90)\end{array}$ & $\begin{array}{r}0.118 * \\
(1.72)\end{array}$ & $\begin{array}{r}-0.015 \\
(1.07)\end{array}$ & $\begin{array}{r}0.01 \\
(0.87)\end{array}$ \\
\hline Export share & & $\begin{array}{l}0.105 \\
(0.61)\end{array}$ & & $\begin{array}{r}-0.037 \\
(0.22)\end{array}$ & & $\begin{array}{r}0.023 \\
(0.46)\end{array}$ \\
\hline Import penetration & & $\begin{array}{r}-0.235 \\
(1.03)\end{array}$ & & $\begin{array}{r}-0.001 \\
(0.00)\end{array}$ & & $\begin{array}{r}-0.015 \\
(0.34)\end{array}$ \\
\hline Stock market capitalization & & $\begin{array}{r}0.002 \\
(0.28)\end{array}$ & & $\begin{array}{l}-0.01 \\
(1.13)\end{array}$ & & $\begin{array}{l}0.003 \\
(0.62)\end{array}$ \\
\hline Dummy Germany (0/1) & $\begin{array}{r}0.003 \\
(0.15)\end{array}$ & $\begin{array}{r}-0.006 \\
(0.31)\end{array}$ & $\begin{array}{r}-0.006 \\
(0.24)\end{array}$ & $\begin{array}{r}-0.004 \\
(0.16)\end{array}$ & $\begin{array}{r}-0.044^{* *} \\
(2.39)\end{array}$ & $\begin{array}{r}-0.028 * \\
(1.80)\end{array}$ \\
\hline Constant & $\begin{array}{r}-0.212^{* * * *} \\
(3.08)\end{array}$ & $\begin{array}{r}-0.047 \\
(0.52)\end{array}$ & $\begin{array}{r}-0.340 * * * \\
(3.19)\end{array}$ & $\begin{array}{l}-0.13 \\
(1.10)\end{array}$ & $\begin{array}{r}-0.159 * * * \\
(3.88)\end{array}$ & $\begin{array}{r}-0.064 \\
(1.51)\end{array}$ \\
\hline Observations $(N * T)$ & 4,240 & 1,374 & 901 & 324 & 4,969 & 1,697 \\
\hline Cross-sections $(N)$ & 236 & 114 & 236 & 114 & 236 & 114 \\
\hline$R^{2}$ & 0.11 & 0.16 & 0.14 & 0.23 & 0.04 & 0.17 \\
\hline
\end{tabular}




\section{Table 5: Determinants of the Relative Volatility of Labor to Capital Income}

The dependent variable is the volatility of conditional labor relative to capital income, computed over a five-year moving window $(t, t+4)$. The explanatory variables are measured in $t$. standard errors have been adjusted for heterogeneity and autocorrelation of unknown form. $t$-values are reported in brackets. Fixed effects panel regressions with the cross-section dimensions being determined by the combination of 11 countries and 22 industrial sectors. HS= high-skilled, MS = medium-skilled, LS = low-skilled. ***, **, $*=$ robust at the $1 \%, 5 \%$, 10\%-level.

\begin{tabular}{|c|c|c|c|c|c|c|c|c|}
\hline & $\begin{array}{l}(1) \\
\text { All } \\
\end{array}$ & $\begin{array}{l}(2) \\
\text { All } \\
\end{array}$ & $\begin{array}{l}\text { (3) } \\
\text { HS }\end{array}$ & $\begin{array}{l}(4) \\
\text { HS }\end{array}$ & $\begin{array}{l}\text { (5) } \\
\text { MS }\end{array}$ & $\begin{array}{l}\text { (6) } \\
\text { MS }\end{array}$ & $\begin{array}{l}\text { (7) } \\
\text { LS }\end{array}$ & $\begin{array}{l}(8) \\
\text { LS }\end{array}$ \\
\hline TFP volatility & $\begin{array}{c}0.297 \\
(0.39)\end{array}$ & $\begin{array}{c}0.618 \\
(0.99)\end{array}$ & $\begin{array}{r}-2.743^{* *} \\
(2.20)\end{array}$ & $\begin{array}{r}-2.396 * \\
(1.67)\end{array}$ & $\begin{array}{r}-0.394 \\
(0.46)\end{array}$ & $\begin{array}{r}0.439 \\
(0.51)\end{array}$ & $\begin{array}{r}-2.252^{*} \\
(1.83)\end{array}$ & $\begin{array}{r}-0.758 \\
(0.64)\end{array}$ \\
\hline Benefit replacement rate & $\begin{array}{c}0.136 \\
(1.26)\end{array}$ & $\begin{array}{r}0.085 \\
(0.62)\end{array}$ & $\begin{array}{r}0.239 \\
(1.13)\end{array}$ & $\begin{array}{r}-0.061 \\
(0.27)\end{array}$ & $\begin{array}{r}-0.037 \\
(0.23)\end{array}$ & $\begin{array}{r}-0.176 \\
(0.94)\end{array}$ & $\begin{array}{r}-0.268 * \\
(1.76)\end{array}$ & $\begin{array}{r}-0.378 * \\
(1.68)\end{array}$ \\
\hline Benefit duration & $\begin{array}{r}-0.034 \\
(0.55)\end{array}$ & $\begin{array}{r}0.06 \\
(0.85)\end{array}$ & $\begin{array}{r}-0.251^{* *} \\
(2.26)\end{array}$ & $\begin{array}{r}0.008 \\
(0.06)\end{array}$ & $\begin{array}{r}-0.091 \\
(1.57)\end{array}$ & $\begin{array}{r}0.003 \\
(0.04)\end{array}$ & $\begin{array}{r}-0.411^{* * *} \\
(3.46)\end{array}$ & $\begin{array}{r}-0.138 \\
(1.29)\end{array}$ \\
\hline Union density & $\begin{array}{r}-0.479 * \\
(1.72)\end{array}$ & $\begin{array}{r}-1.029 \\
(1.44)\end{array}$ & $\begin{array}{r}-1.734 * * * \\
(2.60)\end{array}$ & $\begin{array}{r}-0.055 \\
(0.03)\end{array}$ & $\begin{array}{r}-0.988 * * \\
(2.43)\end{array}$ & $\begin{array}{r}-1.537^{*} \\
(1.82)\end{array}$ & $\begin{array}{r}-0.241 \\
(0.57)\end{array}$ & $\begin{array}{r}-1.325 \\
(1.60)\end{array}$ \\
\hline Political left (0/1) & $\begin{array}{r}0.038 * \\
(1.68)\end{array}$ & $\begin{array}{r}-0.045 \\
(1.11)\end{array}$ & $\begin{array}{r}0.129 * * \\
(2.59)\end{array}$ & $\begin{array}{r}-0.048 \\
(0.53)\end{array}$ & $\begin{array}{l}0.001 \\
(0.02)\end{array}$ & $\begin{array}{l}-0.06 \\
(1.25)\end{array}$ & $\begin{array}{r}0.150^{* * *} \\
(2.81)\end{array}$ & $\begin{array}{r}-0.014 \\
(0.22)\end{array}$ \\
\hline Political right $(0 / 1)$ & $\begin{array}{r}-0.005 \\
(0.17)\end{array}$ & $\begin{array}{r}-0.081^{*} \\
(1.91)\end{array}$ & $\begin{array}{r}0.088 \\
(1.55)\end{array}$ & $\begin{array}{r}-0.055 \\
(0.76)\end{array}$ & $\begin{array}{r}-0.045 \\
(1.21)\end{array}$ & $\begin{array}{r}-0.079 * \\
(1.79)\end{array}$ & $\begin{array}{l}0.055 \\
(0.73)\end{array}$ & $\begin{array}{r}-0.069 \\
(1.28)\end{array}$ \\
\hline Labor share (\%) & $\begin{array}{r}-0.509 * * \\
(2.15)\end{array}$ & $\begin{array}{r}-0.370 * \\
(1.74)\end{array}$ & $\begin{array}{r}-1.250 * * * \\
(3.15)\end{array}$ & $\begin{array}{r}-0.587 \\
(0.81)\end{array}$ & $\begin{array}{r}-0.777 * * * \\
(2.65)\end{array}$ & $\begin{array}{r}-0.690 * * \\
(2.20)\end{array}$ & $\begin{array}{r}-1.078 * * \\
(2.26)\end{array}$ & $\begin{array}{l}-0.69 \\
(1.35)\end{array}$ \\
\hline Share high-skilled & & & $\begin{array}{r}-0.841 \\
(0.71)\end{array}$ & $\begin{array}{r}-5.463^{*} \\
(1.83)\end{array}$ & & & & \\
\hline Share medium-skilled & & & & & $\begin{array}{r}-1.442^{* * *} \\
(3.61)\end{array}$ & $\begin{array}{r}-1.687^{* *} \\
(2.17)\end{array}$ & & \\
\hline Share low-skilled & & & & & & & $\begin{array}{r}2.771^{* * * *} \\
(3.95)\end{array}$ & $\begin{array}{r}2.962 * * * \\
(3.02)\end{array}$ \\
\hline Export share & & $\begin{array}{r}-0.041 \\
(0.11)\end{array}$ & & $\begin{array}{r}-0.032 \\
(0.04)\end{array}$ & & $\begin{array}{r}0.02 \\
(0.04)\end{array}$ & & $\begin{array}{r}-0.366 \\
(0.72)\end{array}$ \\
\hline Import penetration & & $\begin{array}{c}0.188 \\
(0.42)\end{array}$ & & $\begin{array}{r}0.742 \\
(0.91)\end{array}$ & & $\begin{array}{r}0.394 \\
(0.74)\end{array}$ & & $\begin{array}{l}0.972 \\
(1.47)\end{array}$ \\
\hline Stock market capitalization & & $\begin{array}{r}0.073^{*} \\
(1.67)\end{array}$ & & $\begin{array}{r}0.259 * * \\
(1.99)\end{array}$ & & $\begin{array}{r}0.108 \\
(1.60)\end{array}$ & & $\begin{array}{r}0.290 * * \\
(2.56)\end{array}$ \\
\hline Dummy Germany (0/1) & $\begin{array}{r}0.04 \\
(1.21)\end{array}$ & $\begin{array}{c}0.054 \\
(0.91)\end{array}$ & $\begin{array}{r}-0.056 \\
(0.77)\end{array}$ & $\begin{array}{r}-0.043 \\
(0.45)\end{array}$ & $\begin{array}{l}0.018 \\
(0.47)\end{array}$ & $\begin{array}{l}0.065 \\
(0.87)\end{array}$ & $\begin{array}{r}0.046 \\
(0.62)\end{array}$ & $\begin{array}{r}0.201^{* *} \\
(2.27)\end{array}$ \\
\hline Constant & $\begin{array}{r}0.754^{* * *} \\
(3.76)\end{array}$ & $\begin{array}{r}0.670 * \\
(1.97)\end{array}$ & $\begin{array}{r}2.394^{* * *} \\
(5.49)\end{array}$ & $\begin{array}{r}1.442 * \\
(1.93)\end{array}$ & $\begin{array}{r}2.240 * * * \\
(6.78)\end{array}$ & $\begin{array}{r}2.262 * * * \\
(3.31)\end{array}$ & $\begin{array}{r}1.148^{* * *} \\
(2.60)\end{array}$ & $\begin{array}{l}0.514 \\
(0.98)\end{array}$ \\
\hline Observations $(N * T)$ & 4,240 & 1,374 & 4,240 & 1,374 & 4,240 & 1,374 & 4,240 & 1,374 \\
\hline Cross-sections $(N)$ & 236 & 114 & 236 & 114 & 236 & 114 & 236 & 114 \\
\hline$R^{2}$ & 0.04 & 0.05 & 0.03 & 0.04 & 0.06 & 0.07 & 0.06 & 0.11 \\
\hline
\end{tabular}




\section{CESifo Working Paper Series}

for full list see www.cesifo-group.org/wp

(address: Poschingerstr. 5, 81679 Munich, Germany, office@cesifo.de)

2405 Leonidas Enrique de la Rosa, Overconfidence in a Career-Concerns Setting, September 2008

2406 Marcus Drometer and Johannes Rincke, The Design of Political Institutions: Electoral Competition and the Choice of Ballot Access Restrictions in the United States, September 2008

2407 Markku Lanne and Helmut Lütkepohl, Stock Prices and Economic Fluctuations: A Markov Switching Structural Vector Autoregressive Analysis, September 2008

2408 Thomas L. Brewer, International Energy Technology Transfers for Climate Change Mitigations, September 2008

2409 Alexander Kemnitz, Native Welfare Losses from High Skilled Immigration, September 2008

2410 Xavier Vives, Strategic Supply Function Competition with Private Information, September 2008

2411 Fabio Padovano and Roberto Ricciuti, The Political Competition-Economic Performance Puzzle: Evidence from the OECD Countries and the Italian Regions, September 2008

2412 Joan Costa-Font and Mireia Jofre-Bonet, Body Image and Food Disorders: Evidence from a Sample of European Women, September 2008

2413 Thorsten Upmann, Labour Unions - To Unite or to Separate?, October 2008

2414 Sascha O. Becker and Ludger Woessmann, Luther and the Girls: Religious Denomination and the Female Education Gap in $19^{\text {th }}$ Century Prussia, October 2008

2415 Florian Englmaier and Stephen Leider, Contractual and Organizational Structure with Reciprocal Agents, October 2008

2416 Vittorio Daniele and Ugo Marani, Organized Crime and Foreign Direct Investment: The Italian Case, October 2008

2417 Valentina Bosetti, Carlo Carraro, Alessandra Sgobbi and Massimo Tavoni, Modelling Economic Impacts of Alternative International Climate Policy Architectures. A Quantitative and Comparative Assessment of Architectures for Agreement, October 2008

2418 Paul De Grauwe, Animal Spirits and Monetary Policy, October 2008 
2419 Guglielmo Maria Caporale, Christophe Rault, Robert Sova and Anamaria Sova, On the Bilateral Trade Effects of Free Trade Agreements between the EU-15 and the CEEC-4 Countries, October 2008

2420 Yin-Wong Cheung and Daniel Friedman, Speculative Attacks: A Laboratory Study in Continuous Time, October 2008

2421 Kamila Fialová and Ondřej Schneider, Labour Market Institutions and their Effect on Labour Market Performance in the New EU Member Countries, October 2008

2422 Alexander Ludwig and Michael Reiter, Sharing Demographic Risk - Who is Afraid of the Baby Bust?, October 2008

2423 Doina Maria Radulescu and Michael Stimmelmayr, The Welfare Loss from Differential Taxation of Sectors in Germany, October 2008

2424 Nikolaus Wolf, Was Germany ever United? Evidence from Intra- and International Trade 1885 - 1933, October 2008

2425 Bruno S. Frey, David A. Savage and Benno Torgler, Noblesse Oblige? Determinants of Survival in a Life and Death Situation, October 2008

2426 Giovanni Facchini, Peri Silva and Gerald Willmann, The Customs Union Issue: Why do we Observe so few of them?, October 2008

2427 Wido Geis, Silke Uebelmesser and Martin Werding, Why go to France or Germany, if you could as well go to the UK or the US? Selective Features of Immigration to four major OECD Countries, October 2008

2428 Geeta Kingdon and Francis Teal, Teacher Unions, Teacher Pay and Student Performance in India: A Pupil Fixed Effects Approach, October 2008

2429 Andreas Haufler and Marco Runkel, Firms' Financial Choices and Thin Capitalization Rules under Corporate Tax Competition, October 2008

2430 Matz Dahlberg, Heléne Lundqvist and Eva Mörk, Intergovernmental Grants and Bureaucratic Power, October 2008

2431 Alfons J. Weichenrieder and Tina Klautke, Taxes and the Efficiency Costs of Capital Distortions, October 2008

2432 Andreas Knabe and Ronnie Schöb, Minimum Wage Incidence: The Case for Germany, October 2008

2433 Kurt R. Brekke and Odd Rune Straume, Pharmaceutical Patents: Incentives for R\&D or Marketing?, October 2008

2434 Scott Alan Carson, Geography, Insolation, and Institutional Change in $19^{\text {th }}$ Century African-American and White Stature in Southern States, October 2008 
2435 Emilia Del Bono and Daniela Vuri, Job Mobility and the Gender Wage Gap in Italy, October 2008

2436 Marco Angrisani, Antonio Guarino, Steffen Huck and Nathan Larson, No-Trade in the Laboratory, October 2008

2437 Josse Delfgaauw and Robert Dur, Managerial Talent, Motivation, and Self-Selection into Public Management, October 2008

2438 Christian Bauer and Wolfgang Buchholz, How Changing Prudence and Risk Aversion Affect Optimal Saving, October 2008

2439 Erich Battistin, Clara Graziano and Bruno Parigi, Connections and Performance in Bankers' Turnover: Better Wed over the Mixen than over the Moor, October 2008

2440 Erkki Koskela and Panu Poutvaara, Flexible Outsourcing and the Impacts of Labour Taxation in European Welfare States, October 2008

2441 Marcelo Resende, Concentration and Market Size: Lower Bound Estimates for the Brazilian Industry, October 2008

2442 Giandomenico Piluso and Roberto Ricciuti, Fiscal Policy and the Banking System in Italy. Have Taxes, Public Spending and Banks been Procyclical in the Long-Run? October 2008

2443 Bruno S. Frey and Katja Rost, Do Rankings Reflect Research Quality?, October 2008

2444 Guglielmo Maria Caporale, Antoaneta Serguieva and Hao Wu, Financial Contagion: Evolutionary Optimisation of a Multinational Agent-Based Model, October 2008

2445 Valentina Bosetti, Carlo Carraro and Massimo Tavoni, Delayed Participation of Developing Countries to Climate Agreements: Should Action in the EU and US be Postponed?, October 2008

2446 Alexander Kovalenkov and Xavier Vives, Competitive Rational Expectations Equilibria without Apology, November 2008

2447 Thiess Buettner and Fédéric Holm-Hadulla, Cities in Fiscal Equalization, November 2008

2448 Harry H. Kelejian and Ingmar R. Prucha, Specification and Estimation of Spatial Autoregressive Models with Autoregressive and Heteroskedastic Disturbances, November 2008

2449 Jan Bouckaert, Hans Degryse and Thomas Provoost, Enhancing Market Power by Reducing Switching Costs, November 2008

2450 Frank Heinemann, Escaping from a Combination of Liquidity Trap and Credit Crunch, November 2008 
2451 Dan Anderberg, Optimal Policy and the Risk Properties of Human Capital Reconsidered, November 2008

2452 Christian Keuschnigg and Evelyn Ribi, Outsourcing, Unemployment and Welfare Policy, November 2008

2453 Bernd Theilen, Market Competition and Lower Tier Incentives, November 2008

2454 Ondřej Schneider, Voting in the European Union - Central Europe's Lost Voice, November 2008

2455 Oliver Lorz and Gerald Willmann, Enlargement versus Deepening: The Trade-off Facing Economic Unions, November 2008

2456 Alfons J. Weichenrieder and Helen Windischbauer, Thin-Capitalization Rules and Company Responses, Experience from German Legislation, November 2008

2457 Andreas Knabe and Steffen Rätzel, Scarring or Scaring? The Psychological Impact of Past Unemployment and Future Unemployment Risk, November 2008

2458 John Whalley and Sean Walsh, Bringing the Copenhagen Global Climate Change Negotiations to Conclusion, November 2008

2459 Daniel Mejía, The War on Illegal Drugs in Producer and Consumer Countries: A Simple Analytical Framework, November 2008

2460 Carola Frydman, Learning from the Past: Trends in Executive Compensation over the Twentieth Century, November 2008

2461 Wolfgang Ochel, The Political Economy of Two-tier Reforms of Employment Protection in Europe, November 2008

2462 Peter Egger and Doina Maria Radulescu, The Influence of Labor Taxes on the Migration of Skilled Workers, November 2008

2463 Oliver Falck, Stephan Heblich and Stefan Kipar, The Extension of Clusters: Differencein-Differences Evidence from the Bavarian State-Wide Cluster Policy, November 2008

2464 Lei Yang and Keith E. Maskus, Intellectual Property Rights, Technology Transfer and Exports in Developing Countries, November 2008

2465 Claudia M. Buch, The Great Risk Shift? Income Volatility in an International Perspective, November 2008 